\title{
Influence of Organic Amendment on Microbial Activities and Growth of Pepper Cultured on Crude Oil Contaminated Niger Delta Soil
}

\author{
Raimi Morufu Olalekan ${ }^{1}$, Sabinus Chibuzor Ezugwu² \\ ${ }^{1}$ Department of Community Medicine, Environmental Health Unit, Niger Delta University, Wilberforce Island, Nigeria \\ ${ }^{2}$ Department of Environmental Health, University of Uyo, Uyo, Nigeria \\ Email address: \\ ola07038053786@gmail.com (R. M. Olalekan)
}

\begin{abstract}
To cite this article:
Raimi Morufu Olalekan, Sabinus Chibuzor Ezugwu. Influence of Organic Amendment on Microbial Activities and Growth of Pepper Cultured on Crude Oil Contaminated Niger Delta Soil. International Journal of Economy, Energy and Environment.

Vol. 2, No. 4, 2017, pp. 56-76. doi: 10.11648/j.ijeee.20170204.12
\end{abstract}

Received: May 6, 2017; Accepted: August 2, 2017; Published: September 6, 2017

\begin{abstract}
Land contamination with crude oil is one of the challenges of effective crop production in the Niger Delta Region of Nigeria. This condition is inherent thus creates the need for developing effective remedial methods of managing contaminated lands as well as improve crop production. This study was designed to assess the effect of Brewers Spent Grains (BSG) on microbial activities and growth of Capsicum annum L cultured in crude oil contaminated soil. The results have shown that depending on the level of contamination, crude affected both the physical and chemical attributes of soil. It increased the acidity from $\mathrm{pH} 5.67$ to a range of $5.58-5.64$ and the total organic carbon content from $0.05 \%$ to $0.14 \%-0.21$ while the total nitrogen and available phosphorus levels of soil were remarkably reduced from $0.39 \%$ to $0.21 \%-0.28 \%$, and from $0.036 \%$ to $0.028 \%-0.032 \%$ respectively. Amendment of contaminated soil with BSG had variable influence on the microbial properties of test soil. It increases the heterotrophic activity of bacteria in soil while retarding the activities of nitrogen fixing bacteria (Nitrosomonas sp and Nitrobacter sp). However at a stimulating amendment level of $150 \mathrm{~g}$ of BSG in a $0.208 \%$ level of contamination, the activities of hydrocarbon degrading bacteria was enhanced from the hitherto low number of $3.6 \log \mathrm{CFU} / \mathrm{g}$ found in test soil to $6.2 \mathrm{log} \mathrm{CFU} / \mathrm{g}$ obtained on the 6 th week of the remediation period. This resulted in $62.09 \%$ hydrocarbon degradation in soil at the end of the 8-week remediation course. BSG amendment of the oil contaminated had clear but variable influence on some agronomic traits of the cultured pepper. Growth was generally promoted by the amendment and the most significant $(\mathrm{P}<0.05)$ growth attributes affected were the plant height, number of branches, leaves, flowers and fruits as well as the leaf area. Pepper seedlings exposed to $0.624 \%$ of oil and remedied with $300 \mathrm{~g}(1.5 \%)$ had the highest number of flowers but the flower did develop into fruits. However plant exposed to $0.416 \%$ of oil contamination and remedied with $0.75 \%$ of BSG produced flowers that formed fruits. Although the cultured pepper plants exhibited necrotic spots, this study has shown that plants grow in crude oil contaminated soil if alternative source of nutrients is provided. This tend to grow more in lightly contaminated soil and remediation using BSG has proven to enhance the activities of microorganisms and subsequent degradation of hydrocarbons in contaminated soil. It is highly recommended for use as soil conditioner to "unmask" nutrients in contaminated soils.
\end{abstract}

Keywords: Contaminated Land, Organic Amendment, Crude Oil and Microbial Activities

\section{Introduction}

An oil spill happens when liquid petroleum hydrocarbon is released into the environment by vehicle, vessel, wells, or pipe line. It happens on a long scale and is mostly seen in aquatic and terrestrial environments. It happens mostly due to human negligence/activities and is a major form of pollution. The sources of the spill are many. Crude oil can be released by tankers and pipeline vandals on land. In water bodies, the spill occurs due to discharge from drilling rigs, offshore oil platforms, and wells. Oil spills and their effects can also be experienced with refined petroleum or even waste oil from large scale industries. The most common thing in all is that 
the damage caused by them is permanent and takes a long time to clean up (Encyclopedia Britannica, 2012) [23].

Pollution is the introduction of substance, materials, energy and sound into the environment either by man or by nature and either deliberately or accidentally in such an extent that the physical, chemical and biological characteristics of the environment are altered or degraded, affecting the quality, health, use and occupation of the environment, natural resources and their use, man-made materials, human activities and socio-economic well being, posing danger to human health and other life on the earth surface (Raimi, 2008) [45]. Thus, crude oil pollution is the contamination of the environment by the harmful substances from crude oil, for instance via spill. An oil spill is a form of pollution. It is the release of a liquid petroleum hydrocarbon into the environment, especially marine areas, due to human activity. The term is usually applied to marine oil spills, where oil is released into the ocean or coastal waters, but spills may also occur on land. Oil spill may be due to releases of crude oil from tankers, offshore platforms, drilling rigs, and wells as well as spills of refined petroleum products (such as gasoline, diesel) and their by-products, heavier fuels used by large ships suc as bunker fuel, or the spill of any oily refuse or waste oil.

Oil spills can have disastrous consequences for society, economically, environmentally, and socially. As a result of these consequences, oil spill accidents can initiate intense media attention and political uproar. Multiple types of actors in society can become involved in a political struggle on how government should respond to oil spills and what actions prevent them from happening. Despite substantial national and international policy improvements on preventing oil spills adopted in recent decades, large oil spills keep occurring.

Oil spill on water bodies floats on water and prevents sunlight to pass through it and also reduces the levels of dissolved oxygen. The shiny substance that you see sometimes on top layer of water is nothing but oil which makes it difficult for plants and sea fauna to survive. Oil spill can prove fatal for plant, animal and human life. The substance is so toxic that it can cause massive death of species that live in the sea. Crude oil ruins the insulating and waterproofing properties of feathers and fur and thus oilcoated birds and marine mammals may die from hypothermia. Damage to plant life can be considered as well; salt water marshes and mangroves are two notable shore ecosystems that frequently suffer from oil spills.

Petroleum contains non-aromatic, mono-aromatic and an extensive suites of polycyclic aromatic (PAHs) which can be toxic to organisms (Essien, Ebong, Asuquo, and Olajire, 2012) [25] and pose significant hazard to human health and the earth's ecology if spilt. An area of land contaminated with petroleum hydrocarbons may remain totally barren for about ten years after a spill incidence, depending on the quantity of oil in the soil, the soil remediation techniques adopted and many other interacting environmental factors (Abu, and Dike, 2008) [2]. The soil PH of most spill sites fall within the range suitable for plant growth although the nitrogen level of such soil is usually low (Abu, and Dike, 2008) [2]. A heavy oil spill also destroys vegetation causing smothering of the existing plants through direct toxicity. In experimental observations, it seems that the poor growth and development of plants in petroleum contaminated Nigerian ultisols may not necessarily be as a result of direct toxicity of the soil. Thus, it appears that crust formation and possibly nutrients deficiencies may have a more determining factor on plant growth in oil spill sites. Soil pollution especially through the spillage of oil had been identified to cause unsatisfactory growth in plants (Adesua, 2014) [6]. Previous studies had revealed that the crude oil pollutants often resulted insufficient aeration of particles, retard growth of plants, results in chlorosis of leaves and dehydration of plants (Adekunle, 2011) [3].

Studies have shown that the use of compost can improve the physical, chemical, and microbiological characteristics of cultivated soil and increase crop production (Rainbow and Wilson (2002) [46]. However, little has been done or reported regarding the growth and quality of agricultural product, and most studies in this respect are found in the field of organic-biological-biodynamic-ecological agriculture reported by Adesodun and Mbagwu, (2008) [5]. Improvements in the characteristics of the products have been obtained with organic fertilizers, particularly compost, over those obtained with more conventional fertilizer practices based on intensive mineral fertilization (Abioye et al, 2012 [1]; Abu and Dike, 2008) [2]. However some results are contradictory and there are no reports on the use of amendments to stimulate/improve soil quality and crop growth/yield in a previously contaminated soil with residual loads of petroleum hydrocarbons.

The general objective of the study is to evaluate the influence of organic amendment on microbial activities and growth of pepper cultured on crude oil contaminated soil of the Niger Delta. The focus is to stimulate petroleumhydrocarbons-polluted -soil with low level of hydrocarbon contaminates and then evaluate the influence of amendment with brewer's spent grains (BSG) on the growth and yield of pepper cultured on the contaminated soil. The specific objectives are to:

(a). Determine the microbiological and physicochemical properties of soils stimulated with hydrocarbons and amendment;

(b). Estimate the microbiological loads of oil test soil after treatment (with oil and amendment) on plant growth; and

(c). Evaluate the growth rate of pepper grown in test soils. 


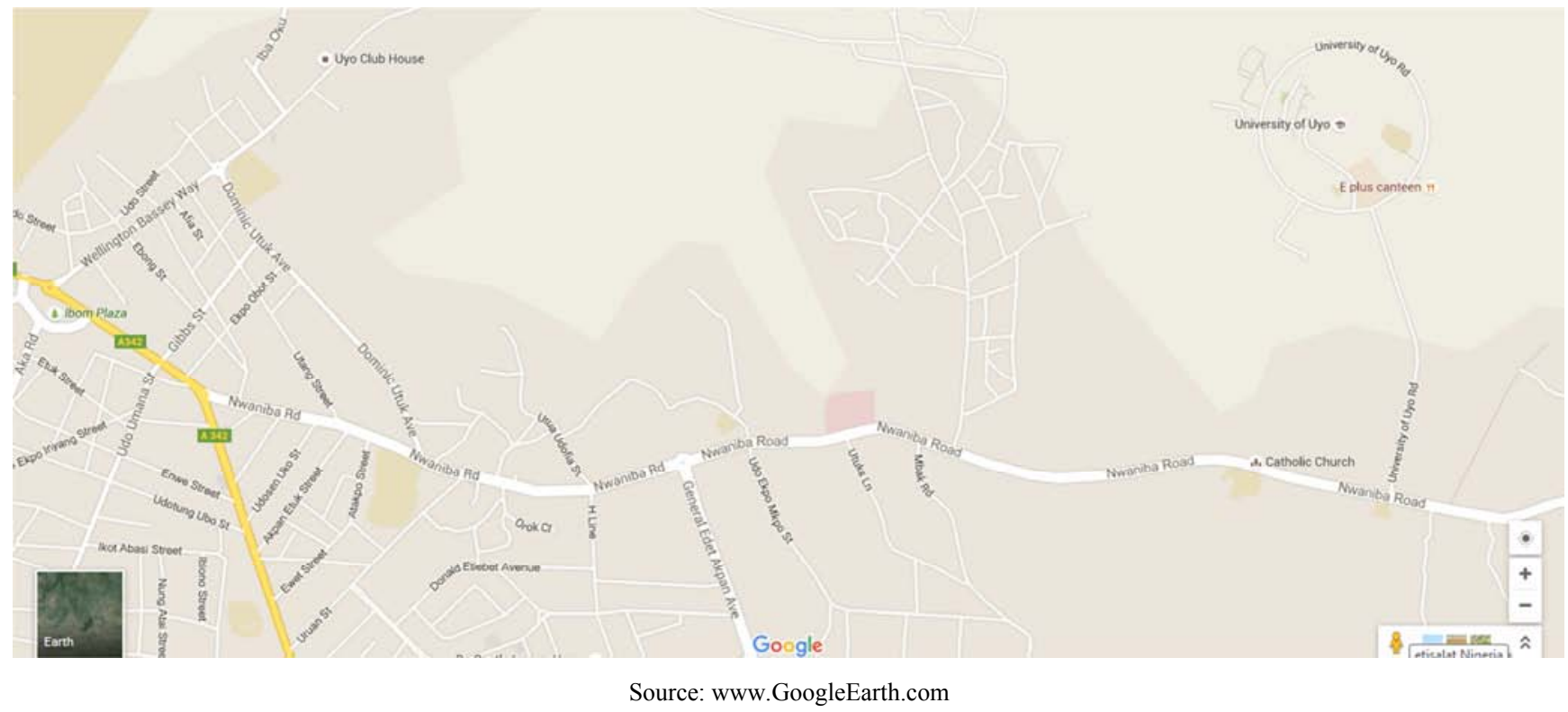

Figure 1. Map of Uyo showing the study area (Uniuyo Permanent Campus).

\section{Materials and Methods}

\subsection{Study Site}

The study was conducted at a site in the University of Uyo Permanent Campus (Figure 1). The Campus is located at latitude $5^{\circ} 2$ ' $\mathrm{N}$ and longitude $7^{\circ} 55^{\prime} \mathrm{E}$ and found along Nwaniba Road, about $4.5 \mathrm{~km}$ from the city centre. Uyo is located within the rainforest zone of Nigeria.

\subsection{Physicochemical Analysis of Test Soil and Organic Amendment}

The chemical and physical properties of the garden soil that was used in this research was determined using standard analytical procedures as recommended in Ekundayo and Obuekwe, (2004) [21]. Prior to analysis, the soil and organic amendment extracts were prepared by rotating upside down $100 \mathrm{~g}$ each of the contaminated, and garden soils in $200 \mathrm{ml}$ of deionized water for 30 minutes followed by centrifuging at $600 \mathrm{~mm}$ for 10 minutes. The $\mathrm{pH}$, total nitrogen, organic carbon, available phosphorus, exchangeable cations and the particle size distribution of the test soil was determined using recommended protocols. Nutritive salts content of the soil were also determined using standard analytical procedures.

The physicochemical properties of organic amendment were also determined. Fresh weight of each amendment was recorded before drying to constant weight in a Gallenkamp oven at $60^{\circ} \mathrm{C}$ for three days and dry weight recorded. The nutritive properties of the amendment were determined. Properties such as $\mathrm{pH}$, total nitrogen, crude protein, lipid, ligno-cellulose, total organic carbon and mineral matter were determined using standard methods. The water-soluble phosphate and other nutritive salts such as nitrate $\left(\mathrm{NO}_{3}{ }^{-}\right)$, sulphate $\left(\mathrm{SO}_{4}{ }^{2-}\right)$ and chloride $\left(\mathrm{CL}^{-}\right)$were also measured. Details of the analytical protocols adopted are as follows.

(a). $\mathrm{pH}$
This was determined at the point of collection using $\mathrm{pH}-$ meter embedded in multi - combi meter.

(b). Available Phosphorus

The estimation of phosphorus was carried out using the Adesua, (2014) [6] method about $0.5 \mathrm{~g}$ of finely ground well mixed soil or BSG samples were weighed into different $100 \mathrm{ml}$ Telfon beaker. About $5 \mathrm{ml}$ conc. $\mathrm{H}_{2} \mathrm{SO}_{4}$ was added and swirled gently. $3 \mathrm{ml}$ of $30 \% \mathrm{H}_{2} \mathrm{O}_{2}$ was added in $0.5 \mathrm{ml}$ potions and swirled vigorously. When the reaction subsided $1 \mathrm{ml}$ of hydrofluoric acid was added in $0.5 \mathrm{ml}$ potions and swirled gently. The beaker was placed on a hot plate at $150^{\circ} \mathrm{C}$ for 10 12 mins to eliminate excess $\mathrm{H}_{2} \mathrm{O}_{2}$. After cooling, the contents of the flasks were transferred quantitatively to a $50 \mathrm{ml}$ quantitative flask, passing it through a quantitative filter paper. Two additional washings of the beaker were made each with $10 \mathrm{ml}$ distilled water. These were filtered and made up to exact volume.

(c). Determination of Total Organic Carbon

The carbon content of the samples were determined using Adesua (2014) [6] method. One (1.0) g of each sample was weighed into $500 \mathrm{ml}$ conical flask each. $10 \mathrm{ml}$ of $1 \mathrm{~N} \mathrm{~K}_{2} \mathrm{Cr}_{2} \mathrm{O}_{2}$ and $20 \mathrm{ml}$ of conc. $\mathrm{H}_{2} \mathrm{SO}_{4}$ was added. The flasks were swirled carefully and allowed to stand for 30 minutes. $200 \mathrm{ml}$ of distilled water and $10 \mathrm{ml} \mathrm{H}_{2} \mathrm{PO}_{4}$ was slowly added. $1 \mathrm{ml}$ of diphenylamine indicator was added and titrated against $0.5 \mathrm{~N}$ ferrous ammonium sulphate solutions until green colour started to appear indicating the end point.

Calculation:

$$
\text { Organic Carbon }(\%)=\frac{10(\mathrm{~B}-\mathrm{S}) \times 0.39 \times \mathrm{mcf}}{\mathrm{B} \times \mathrm{W}}
$$

Where:

$\mathrm{B}=\mathrm{ml}$ of ferrous ammonium sulphate solution used for blank

$\mathrm{S}=\mathrm{ml}$ of ferrous ammonium sulphate solution used for the sample 
$\mathrm{mcf}=$ Moisture correction factor

$\mathrm{W}=$ sample weight $(\mathrm{g})$

$0.39=$ conversion factor (including a correction factor for a supposed $70 \%$ oxidation of organic carbon.

(d). Determination of Total Nitrogen Content

Total Nitrogen was determined by Kjeldahl digestion method according to Adesua, (2014) [6]. Precisely $2 \mathrm{~g}$ of finely ground sample was weighed into a Kjeldahl digestion flask. Thereafter $10 \mathrm{~g}$ of $\mathrm{K}_{2} \mathrm{SO}_{4}$ and $0.5 \mathrm{~g}$ of copper sulphate and $20 \mathrm{ml}$ of $\mathrm{H}_{2} \mathrm{SO}_{4}$ were added. The flask was heated gently till frothing subsides. The heat was gradually increased until a clear digest was obtained. The flask was gradually cooled by slowly adding distilled water to a volume of $50 \mathrm{ml}$. The digest was transferred into a distillation flask and $20 \mathrm{ml}$ of $20 \%$ $\mathrm{NaOH}$ was added into the flask. The digest was distilled into Boric acid indicator by closing the stem of the bypass until the distillate reached $35 \mathrm{ml}$ mark on Erlenmeyer flask. The end of the condenser was raised and total nitrogen was determined by filtrating with $0.05 \mathrm{~N} \mathrm{HCl}$

(e). Determination of Chloride Content of Samples

Chloride content the samples was determined titrimetrically by silver nitrate method or Argentometric method (Adesua, 2014) [6]. The method requires titrating an aliquot portion of sample suspension in the presence of potassium chromate as indicator to bride-red end point with silver nitrate that was standardized with sodium chloride.

(f). Determination of Nitrate Content of Samples

Nitrate content of the sample was determined calorimetrically by UV/visible $\mathrm{HACH}$ spectrophotometer (Adesua, 2014) [6]. The method is based on a yellow complex formation between brucine sulphate and nitrate in the presence of sulphuric acid. The measurement was taken at a wave length of $400 \mathrm{~nm}$. The spectrophotometer was calibrated with working standards from neat potassium nitrate salts.

(g). Determination of Sulphate Content

The sulphate content of the samples was determined turbidimetrically with UV/visible HACH Spectrophotometer at wavelength of $425 \mathrm{~nm}$ (Adesua, 2014) [6]. The method is based on precipitation of sulphate ion in an acetic acid medium with barium chloride (precipitating agent). The reaction, formed barium sulphate crystals of uniform size. Light absorbance of the barium sulphate suspension was measured and the $\mathrm{SO}_{4}^{-2}$ concentration in $\mathrm{mg}^{-1}$ was determined by comparison with standards. Prior to analysis of the samples the equipment was calibrated with sulphate working standards prepared from neat sulphate salts.

(h). Determination of Exchangeable Cations

Exchangeable cations $\left(\mathrm{Ca}^{2+}, \mathrm{Mg}^{2+}, \mathrm{K}^{+}\right.$and $\left.\mathrm{Na}^{+}\right)$were determined using $1 \mathrm{M} \quad \mathrm{NH}_{4} \mathrm{OAc}$ (Ammonium acetate) buffered at $\mathrm{pH} 7.0$ as extractant (Adesua, 2014) [6]. The $\mathrm{K}^{+}$ and $\mathrm{Na}^{+}$concentrations in the soil sample were determined using Gallenkamp flame photometer while $\mathrm{Ca}^{2+}$ and $\mathrm{Mg}^{2+}$ concentrations were determined using Perkin - Elmer Model 403 atomic absorption spectrophotometer (AAS).

(i). Determination of Particle Size in Soil Samples

The hydrometer method of Adesua, (2014) [6]. was used to determine the grain size of test soil. The method requires the determination of particles size, larger than $63 \mathrm{~m}$ by sieving and particle sizes smaller than $63 \mathrm{~m}$ were determined using hydrometer with calgon (sodium hexametaphosphate) as the displacing agent. The hydrometer was calibrated so that the corrected reading gives the grams of sediment materials in suspension. The sand settled to the bottom of the cyclinder within 40 seconds. Therefore, the 40 seconds hydrometer reading gave the amount of silt and clay in suspension. The weight of sand in the sample was obtained by subtracting the corrected hydrometer reading from the total weight of the sample.

$$
\% \text { sand }=\frac{\text { weight of sand }}{\text { Weight of sample } 1} \times 100
$$

To determine the percentage clay in the sample, the suspension was re-shaken and the hydrometer reading was taken at the end of 2 hours and corrected. The corrected hydrometer reading therefore represents the gram of clay in the sample.

$$
\% \text { sand }=100 \%-(\% \text { sand }+\% \text { clay })
$$

(j). Determination of Crude Protein in BSG (Kjeldahl Method)

The Kjeldahl method is the standard method of nitrogen determination. The procedure consists of three basic steps:

1) digestion of the sample in sulfuric acid with a catalyst, which results in conversation of nitrogen to ammonia;

2) distillation of the ammonia into a trapping solution; and

3) quantification of the ammonia by titration with a standard solution.

Weigh out approximately $1 \mathrm{~g}$ forage samples (BSG) on \#1 Whatman filter paper circles. Record weight to nearest 0.1 mg. Fold filter paper around forage and put in Kjeldahl flasks. Run one blank with each set. An laboratory standard forage sample should also be run to gauge acceptability of the run. Put one Kjeldahl packet and 2-3 boiling chips in flask with sample. Add $30 \mathrm{ml}$ sulfuric acid. Turn on water aspirator of the Kjeldahl unit. Also turn on ventilation fan for fume extraction. Digest on Kjeldahl unit for 2 hours with burners on high. Turn flasks a half turn after one half hour of digesting. After 2 hours, turn off burners and let flasks sit for 5-10 minutes. Remove flasks from burners and cap immediately with rubber stoppers and place on Kjeldahl rack. Turn off water aspirator. Let flasks cool for at least 30 minutes. Distillation: Put $50 \mathrm{ml}$ of boric acid in $500 \mathrm{ml}$ Erlenmeyer flasks for each sample being run. Put these flasks on the Kjeldahl unit for distillation. Make sure the sodium hydroxide and water burettes are filled and turn on water for condensing. Turn burners on high. $8.11 \mathrm{In}$ the following order, add $250 \mathrm{ml}$ distilled water, 3-4 chips of mossy zinc, and $100 \mathrm{ml}$ sodium hydroxide slowly. Immediately attach to the condenser. Turn off burners and move flasks off the condenser tubes when the liquid reaches $200 \mathrm{ml}$. Distillation takes about 30 minutes. Shut off water and wash Kjeldahl flasks when all done. Titration: Titrate the liquid in the Erlenmeyer flask using $0.1 \mathrm{~N}$ sulfuric acid until the blue 
liquid returns to a purplish pink color. Be careful not to add too much sulfuric acid. Read ml of sulfuric acid used on burette and record number.

Calculations:\% Crude Protein $=\{(\mathrm{ml}$ titrated- blank $)$ $(.8756) /$ (sample wt in grams) $(\%$ lab DM $)\} * 100$

Where: $\mathrm{DM}=$ Dry Matter and 0.8756 is the conversion factor.

\section{(k). Determination of Mineral matter in BSG}

Analytical method for mineral compositions of BSG. For the determination of minerals constituent, about $0.5 \mathrm{~g}$ of each of the ground samples were digested with $\mathrm{HCLO}_{4}$ and $\mathrm{HNO}_{3}$ Which lasted for $2 \mathrm{hrs}$ and were allowed to cool. Thereafter, the digested sample was transferred into $250 \mathrm{ml}$ volumetric flask and was making up with distilled water. The samples were then ready for analysis using Atomic Absorption Spectrophotometer (AAS) with model no 210 VGP AOAC (2005) [10].

(1). Determination of Lignocellulose in BSG

Step 1: Acid Hydrolysis of the Sample

When this Method is the first step in the Analysis Package, the acid hydrolysis takes place on the biomass sample with no prior extraction carried out at Celignis. If previous Steps involving the extraction of the sample have take place then the extracted material is used for the acid hydrolysis. In the case where three different types of extracted material exist (water-extracted, ethanol-extracted, and water - then ethanolextracted) then the sample that has undergone both water and ethanol extraction is typically used for acid hydrolysis, unless otherwise requested by the customer.

Step 2: Hydrolysate Dilution and Storage

Following the Acid Hydrolysis Step, the hydrolysate (the filtrate from the vacuum filtration) is diluted by a factor of 5 using a fucose-in-water solution. Fucose is the internal standard that is used in the chromatographic analysis of the hydrolysate. Following this dilution the samples are either immediately put on the chromatography system or stored in a freezer for future analysis.

Step 3: Chromatographic Analysis of the Hydrolysate

Ion Chromatography: A Dionex ICS-3000 system that is equipped with electrochemical, conductivity, and ultravioletvisible detectors.

\subsection{Determination of Heavy Metals}

1 gram of well mixed spent grains sample was digested in $20 \mathrm{ml}$ aqua regia (a mixture of concentrated $\mathrm{HCl}$ and $\mathrm{HNO}_{3}$ in a ratio $3: 1$ ) and $25 \mathrm{ml}$ of deionized water in a $250 \mathrm{~mL}$ beaker with watch glass and placed on a hot plate for 3-4 hours at a temperature of about $110 \mathrm{oC}$. After evapouration to dryness, the sample was diluted with $20 \mathrm{ml}$ of deionized water and transferred into a $100 \mathrm{ml}$ volumetric flask after filtering through Whatman filter paper No. 42 and diluted to $100 \mathrm{ml}$ mark. The extract was then analyzed for the concentration of heavy metals using Atomic Absorption Spectrophotometer (AAS) model; AAS40FS and aqueous calibration standards prepared from stock standard solution of the respective elements (buck scientific) according to the methods of Emufurieta et al, 1992
[22] and Aweke and Taddese, 2004 [12].

\subsection{Determination of Total Petroleum Hydrocarbons (TPH) Content of Untreated and Remedied Soils}

The analyses of TPH in both untreated and remedied soil samples were carried out using the modified EPA 8015 (i.e.8015B) of International Standard (AOAC 2005) [10] [30]. Residual TPH in the soil samples was extracted using a mixture of dichloromethane/acetone and the resulting extracts analyzed/quantified by Capillary Column Gas Chromatography fitted with Flame Ionization Detector (GC/FID) and the analytes also fractionated according to their molecular weights. The current GC-FID method for TPH is a modification of EPA Method 8015, which was designed to measure discrete non-halogenated organics, including polar compounds such as alcohols, ketones, and aldehydes.

\subsection{Bioremediation Studies}

A randomized block design approach was adopted using perforated wooden boxes (Plate 1). In this design, 20kg each of the garden soil was carefully weighed and transferred into $12 \times 12 \mathrm{~cm}$ square wooden boxes in replicates of four and thereafter contaminated with graded doses of crude oil; $150 \mathrm{ml}, 100 \mathrm{ml}, 50 \mathrm{ml}$, and $0 \mathrm{ml}$ representing $0.624 \%, 0.416 \%$, $0.208 \%$ and $0 \%$ (control) residual loads of hydrocarbon. The crude oil simulated boxes were allowed to condition for 2 days before treatment with organic amendment. The organic amendment (BSG) was introduced by base application in the ratios of 1:1, 1:2, 1:3, and 1:4 of Crude oil: Amendment mixture. Precisely the four treatments were amended with 150, 300, 450, 600 grams of BSG. The amended soil was allowed to stay for one week before transplanting of the pepper seedling.

Two sets of control experiments were constituted. One comprising un-contaminated test soil plus Organic amendment (Control-1) and another comprising uncontaminated and un-amended test soil (Control-2).

The wooded boxes were perforated to avoid water logging and were placed in the Department of Botany and Ecological Studies, University of Uyo Green-house for observation. The set up was routinely watered stream water and allowed over time for the crop to grow.

\subsection{Microbiological Analysis of Organic Amendment, Untreated and Treated Soil}

Standard microbiological techniques were employed during this study. The microbiological properties of the BSG (organic amendment) and test soil were determined prior to use for the bioremediation studies. On the other hand the microbiological properties of the soil during the remediation course were determined at 7 days interval for a period of 8 weeks (56 days).

\subsection{Estimation Heterotrophic Bacterial Loads}

The density of the total heterotrophic bacteria (THBC) was 
assessed on nutrient agar using the pour plate technique as described by Adesua (2014) [6].

\subsection{Estimation of Densities of Nitrosomonas and Nitrobacter}

Nitrosomonas and Nitrobacter were determined using the pour plate technique as described by Adesua (2014) [6] with slight modification.

\subsection{Estimation of Densities of Hydrocarbonoclastic Bacteria}

Hydrocarbon degrading bacteria were isolated by a modified enrichment - culture technique of Tian et al (2008) [53] using mineral salt medium as the analytical substrate.

\subsection{Characterization of Bacterial Isolates}

The bacterial isolates were characterized based on their cultural and morphological attributes as well as their responses to standard biochemical test as described by Cheesbrough, (2006) [16]. Twenty four hours old monocultures of bacteria obtained were subjected to Gram's and endospore staining and several biochemical test such as Catalase test, Citrate Utilization test, Oxidase test, Motility test, Endospore, Methyl red and Vogues Proskauer test and Indole test, as well as sugar fermentation test. The results obtained were compared with characteristics described in Bergey's Manual of Determinative Bacteriology (Adesua, 2014) [6].

\subsection{Determination of Plant Growth Parameters}

Apparently healthy four seedlings each were transplanted from the nursery into each wooden box. The transplanted seedlings were watered twice daily and allowed to grow to maturity. The effect of the organic amendment on the growth of pepper cultured on oil contaminated was evaluated.

\subsection{Shoot Height, Number of Branches and Number of Leaves}

The shoot height was determined by measuring shoot height $(\mathrm{cm})$ from the base to the tip of the plants. Measurements were taken for four replicates. The number of branches and leaves of the test plants were counted visually from each plant. Averages of four determinations were determined.

\subsection{Leaf Area}

Open Leaves of the test plants were harvested and transferred to the laboratory where the leaves area was traced on graph and the total area calculated based on the number of squares within the traced region. The leaf length (LL) and width (LW) were carefully measured using a meter rule while the leaf area was estimated as described by Miyoshi et al. (1996) [36] and Adesua, (2014) [6]. Leaf area (LA) was determined by multiplying leaf length by leaf width with the correction coefficient (r) which is 0.72 .
The Leaf area (LA) was determined according to the formula:

$$
\mathrm{LA}=\mathrm{L} \times \mathrm{W} \times 0.72 .
$$

Where:

$\mathrm{L}$ is the leaf length,

$\mathrm{W}$ is the leaf width and 0.72 is a correction coefficient [factor].

\subsection{Fruiting Age of Test Plant}

The time of flowering (when flower buds were visible) was also monitored and recorded.

\subsection{Statistical Analysis}

Results obtained from the investigation were expressed as mean \pm standard error of mean (SEM) and statistically analysed using Two-way Analysis of Variance (ANOVA). Post hoc test was conducted to evaluate the significance of the differences between the mean values of the measured parameters in the respective test and the control groups, using Student-Newman-Keuls test and the level of significance was considered at $\mathrm{P}=0.05$ (Adesua, 2014) [6].

\section{Results}

\subsection{Physico-chemistry of Brewers Spent Grains (BSG) and Test Soils}

The results of the physicochemical analysis of the organic amendment (BSG) and test soil before and after contamination with various levels of are shown in the Table 1. The parameters analyzed are $\mathrm{pH}$, total organic carbon, total phosphorus, total nitrogen, soil texture, percentage sand, silt, and clay, chloride, nitrate, sulphate, heavy metals (copper, lead, cadmium, and iron) and nutritive salts (calcium, potassium, sodium and magnesium). The results have revealed an acidic soil ( $\mathrm{pH}$ of 5.67) characterized with low level of total organic carbon content $(0.05 \%)$. The total nitrogen content of $0.39 \%$, available phosphorus level of $0.026 \%$ and cation levels of $2.83 \mathrm{mg} / \mathrm{kg}, 1.68 \mathrm{mg} / \mathrm{kg}, 10.47$ $\mathrm{mg} / \mathrm{kg}$ and $0.95 \mathrm{mg} / \mathrm{kg}$ recorded for calcium, potassium, sodium and magnesium respectively revealed a relatively fertile soil with a sandy loam texture and low petroleum hydrocarbons content $(0.0244 \mathrm{mg} / \mathrm{kg})$. The soil was nutritive salts laden but the concentrations of metals were generally low. The values recorded ranged from $1.458 \mathrm{mg} / \mathrm{kg}$ to 5115.7 $\mathrm{mg} / \mathrm{kg}$ recorded for $\mathrm{Pb}$ and $\mathrm{Fe}$ respectively. Depending on the level of contamination, simulation of soil with crude affected both the physical and chemical attributes especially the nutritional status of the test soil. It increases the acidity, total organic carbon and heavy metals content of the soil. Contamination of soil with crude oil also increased the nutritive salts content of the soil but remarkably reduces the total nitrogen and available phosphorus levels of the test soil. Its effect on soil physical attributes was variable with the silt and clay fractions being the most affected textural properties. 
On the other hand, the properties of the organic amendment used for the remediation study shows that the spent grain is rich in nitrate $(10.1 \mathrm{mg} / \mathrm{kg}), \mathrm{K}(2.9 \mathrm{mg} / \mathrm{kg}), \mathrm{Na}$
(4.1 $\mathrm{mg} / \mathrm{kg}$ ) and crude protein (17.8\%). It also has remarkable cellulose content $(24.5 \%)$ and mineral matter (ash content) of $15 \%$ but low in lignocellulose content (3.2\%).

Table 1. Physicochemical properties of the organic amendment and test soil after simulation with different concentrations of crude oil.

\begin{tabular}{|c|c|c|c|c|c|}
\hline Parameter & BSG & Garden soil (control) & Soil A (2075mg/kg) & Soil B (4150mg/kg) & Soil C (6225mg/kg) \\
\hline $\mathrm{pH}$ & 6.64 & 5.67 & 5.64 & 5.61 & 5.58 \\
\hline TOC (\%) & 10.7 & 0.05 & 0.14 & 0.17 & 0.21 \\
\hline Available P (\%) & 0.75 & 0.036 & 0.032 & 0.031 & 0.028 \\
\hline Soil Texture & & Sandy loam & Sandy loam & Sandy loam & Sandy loam \\
\hline Sand $(\%)$ & ND & 76.0 & 82.4 & 68.7 & 76.1 \\
\hline Silt (\%) & ND & 5.9 & 9.0 & 13.1 & 11.3 \\
\hline $\mathrm{Cl}(\mathrm{mg} / \mathrm{kg})$ & 0.001 & 79.98 & 79.98 & 39.99 & 99.97 \\
\hline $\mathrm{NO}_{3}{ }^{-} \mathrm{N}(\mathrm{mg} / \mathrm{kg})$ & 10.1 & 0.025 & 0.106 & 0.051 & 0.01 \\
\hline $\mathrm{SO}_{4}{ }^{2-}(\mathrm{mg} / \mathrm{kg})$ & 1.34 & 14.404 & 10.124 & 8.558 & 11.690 \\
\hline $\mathrm{Cu}(\mathrm{mg} / \mathrm{kg})$ & 1.54 & 3.121 & 5.657 & 4.246 & 4.869 \\
\hline $\mathrm{Pb}(\mathrm{mg} / \mathrm{kg})$ & ND & 1.458 & 6.225 & 5.080 & 6.412 \\
\hline $\mathrm{Cd}(\mathrm{mg} / \mathrm{kg})$ & ND & 0.075 & 0.512 & 0.357 & 0.468 \\
\hline $\mathrm{Fe}(\mathrm{mg} / \mathrm{kg})$ & 50.42 & 5012.45 & 5115.709 & 5064.636 & 5137.11 \\
\hline $\mathrm{Ca}(\mathrm{mg} / \mathrm{kg})$ & 1.04 & 2.835 & 2.968 & 3.137 & 2.884 \\
\hline $\mathrm{Na}(\mathrm{mg} / \mathrm{kg})$ & 4.1 & 10.471 & 10.582 & 9.334 & 11.537 \\
\hline $\mathrm{Mg}(\mathrm{mg} / \mathrm{kg})$ & 2.01 & 0.956 & 0.852 & 1.031 & 0.948 \\
\hline Crude Protein (CP) & 17.8 & ND & ND & ND & ND \\
\hline Cellulose (\%) & 24.6 & ND & ND & ND & ND \\
\hline Lignocellulose (\%) & 3.2 & ND & ND & ND & ND \\
\hline Mineral matter (\%) & 15.12 & ND & ND & ND & ND \\
\hline
\end{tabular}

$\mathrm{ND}=$ Not determined

\subsection{Microbiological Properties of Test Soil and Bio- stimulant}

The results presented in Table 2 revealed the microbiological properties recorded for the garden soil and organic amendments (spent grain) used for the remediation study. The results have revealed the rich microbial assemblage and diversity of the garden (test) soil used. The data derived have shown that the heterotrophic bacterial densities ranged from $2.0 \times 10^{7}$ in test soil to $2.67 \times 10^{4} \mathrm{cfu} / \mathrm{g}$ in BSG, while the hydrocarbonoclastic bacterial densities varied between $4.0 \times 10^{2}$ in soil and $2.1 \times 10^{1} \mathrm{cfu} / \mathrm{g}$ in BSG. Nitrosomonas bacterial densities $3.3 \times 10^{3} \mathrm{cfu} / \mathrm{g}$ and Nitrobacter bacterial densities $1.7 \times 10^{3} \mathrm{cfu} / \mathrm{g}$ were also encountered in the test soil whereas that of the BSG was not detected. The BSG however contained remarkable density of heterotrophic bacteria, very low density of oil degrading bacteria while Nitrosomonas and Nitrobacter were not detected.

Table 2. Microbiological properties of test soil and biostimulants.

\begin{tabular}{lll}
\hline Microbial group & Soil & Spent grain \\
\hline Heterotrophic bacterial count & $2.0 \times 10^{7}$ & $2.67 \times 10^{4}$ \\
Hydrocarbonoclastic bacterial count & $4.0 \times 10^{2}$ & $2.1 \times 10^{1}$ \\
Nitrosomonas count & $3.3 \times 10^{3}$ & ND \\
Nitrobacater count & $1.7 \times 10^{3}$ & ND \\
\hline
\end{tabular}

Values are mean of three determinations. ND = not detected

\subsection{Influence of Spent Grain on the Activities of Bacteria in Crude Oil Contaminated Soil}

Analysis of the effects of graded levels of BSG treatment on soil contaminated with low level of crude oil was investigated. The Influence of the different levels of organic amendment (spent grain) on the activities of heterotrophic, nitrifying bacteria and oil degrading bacteria in garden soil contaminated with crude oil are presented in Figures 2 - 4. The results showed variation in densities of different bacterial groups. At $50 \mathrm{ml} . . . \% \%$ of crude oil contamination the application of $150 \mathrm{~g}$ spent grain resulted in a sharp increase in the density of oil degrading bacteria within two weeks of exposure (Figure 2). However the densities of oil degrading bacteria, Nitrosomonas and Nitrobacter growth decreased drastically between week 7 and 8 in contrast with the sharp increase observed in total heterotrophic count. The results showed the amendments supported more heterotrophic than hydrocarbonoclastic activities.

At $100 \mathrm{ml}-\%$ level of contamination the application of 300 $\mathrm{g}$ of spent grain, the density of heterotrophic bacteria was neither increasing nor decreasing depicting a stationary phase bacteria activities throughout the remediation period. However the number of oil degraders increased over time while the densities of Nitrosomonas and Nitrobacter were retarded during the remediation period (Figure 3). At this level, it is assumed that the BSG had a positive effect on degradation of the pollutants.

In soil contaminated $150 \mathrm{ml} \% \%$ of crude oil, the application of $600 \mathrm{~g}$ of spent grain, the results presented in Figure 4 
showed remarkable increase in density of heterotrophic bacterial count between the 6th and 8th week of exposure while the growth of oil degrading bacteria, Nitrosomonas and Nitrobacter showed a decreasing trend throughout the remediation study. This result shows that the higher the level of amendment the less the activity of oil degrading bacteria.

The changes in bacterial activities of the unpolluted soil over time are presented in Figure 5. The result recorded revealed fluctuation in activities of Nitrosomonas and Nitrobacter during the exposure time with decline or dead phase in the 7th week of exposure while the counts of total heterotrophic bacteria and oil degrading bacteria decreased over time.

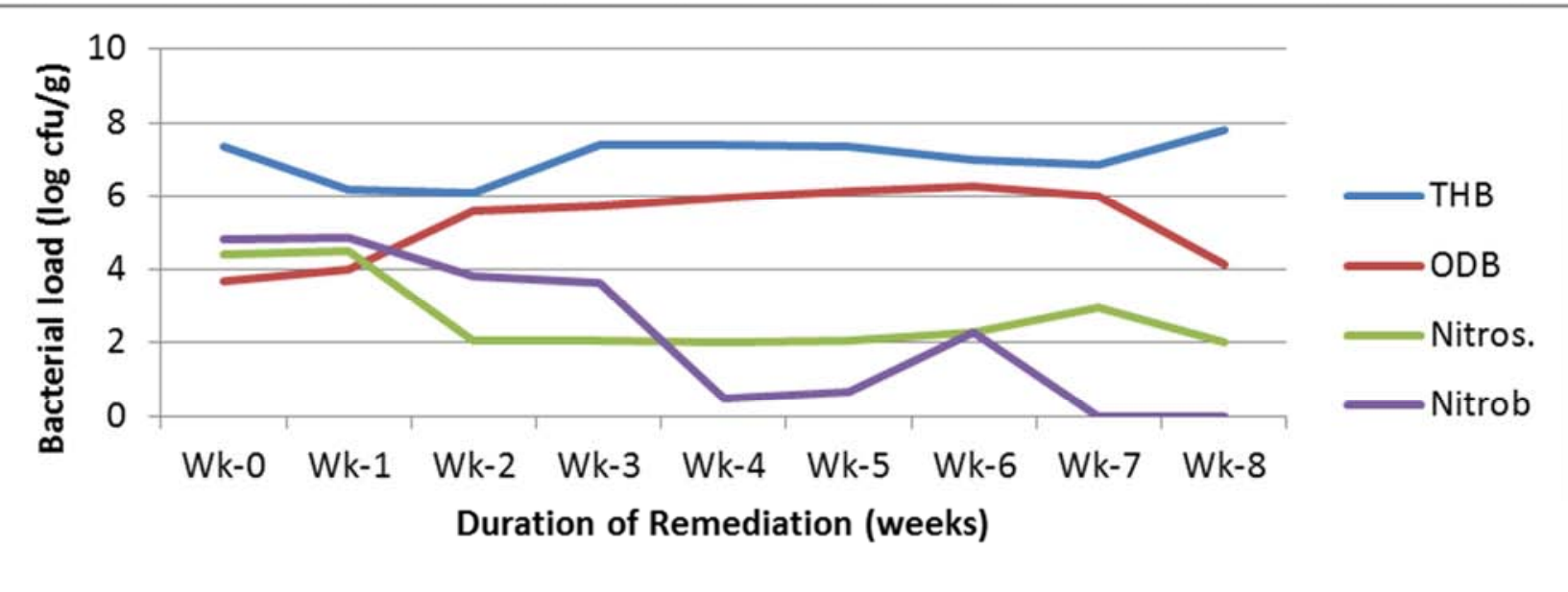

Figure 2. Influence of $150 \mathrm{~g}$ of BSG application on the bacterial activities in garden soil contaminated with $50 \mathrm{ml}$ crude oil.

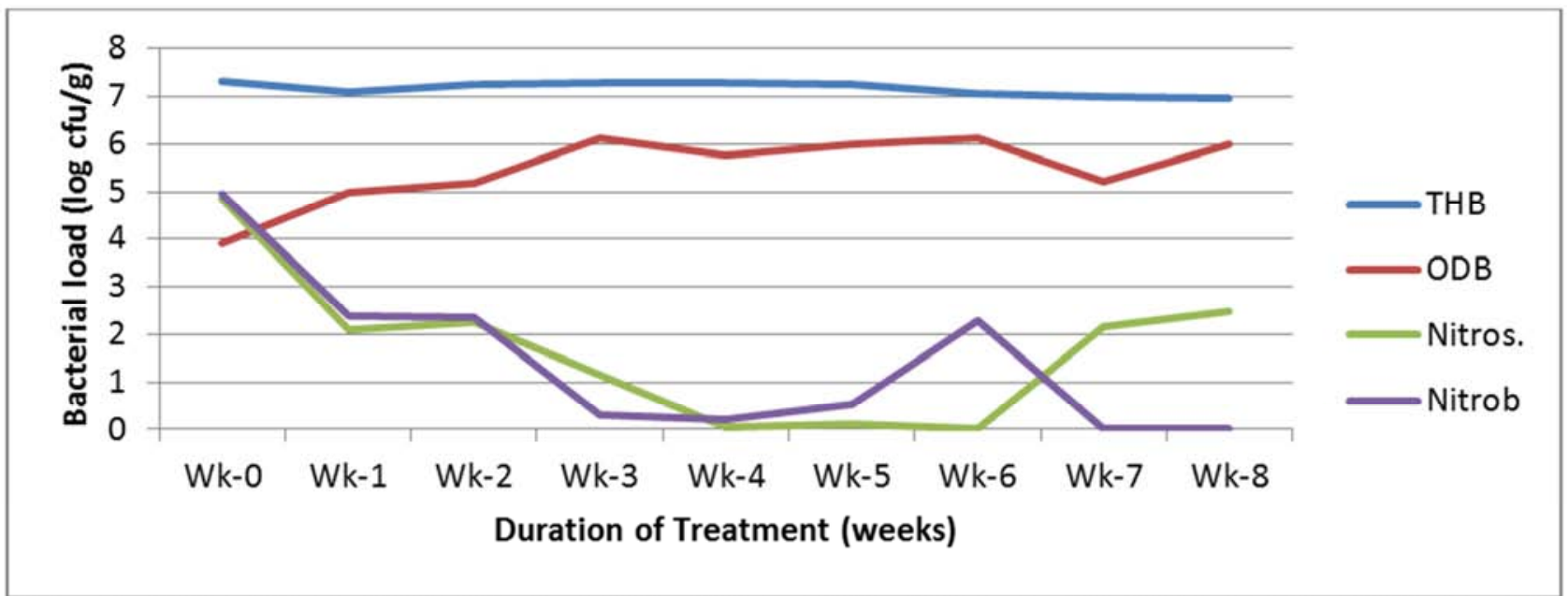

Figure 3. Influence of $300 \mathrm{~g}$ of BSG application on the bacterial activities in garden soil contaminated with $100 \mathrm{ml}$ crude oil.

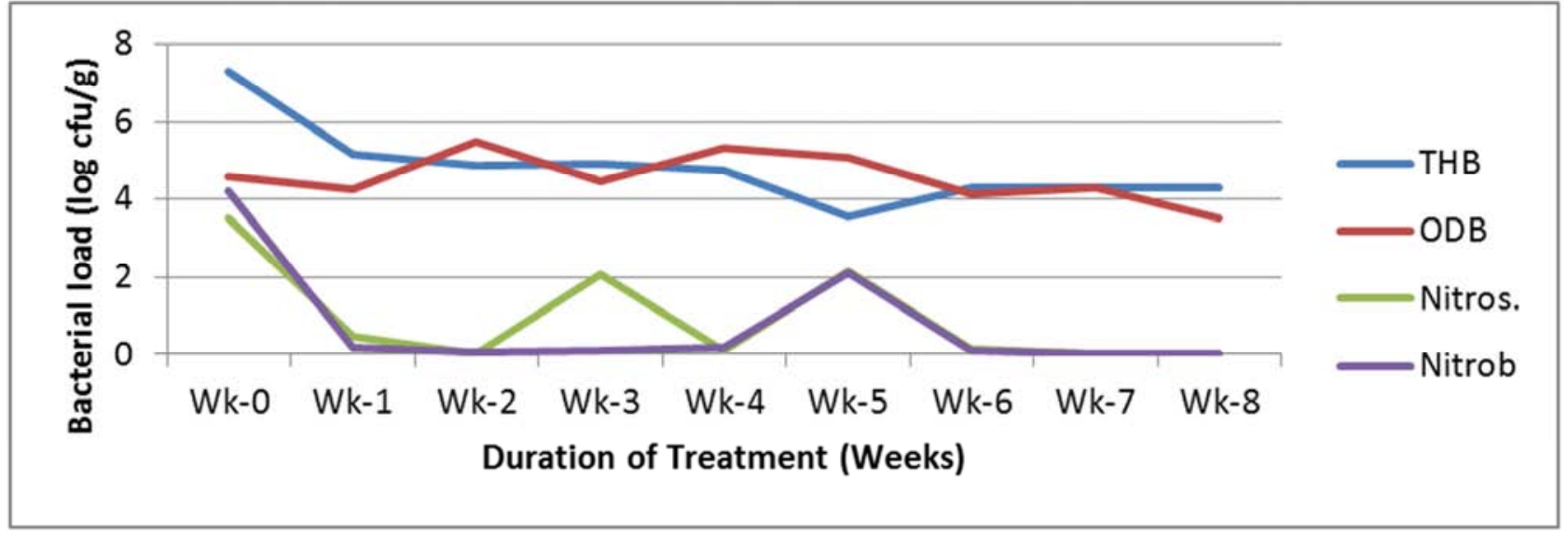

Figure 4. Influence of $600 \mathrm{~g}$ of BSG application on the activities of bacteria in garden soil contaminated with $150 \mathrm{ml}$ of crude oil. 


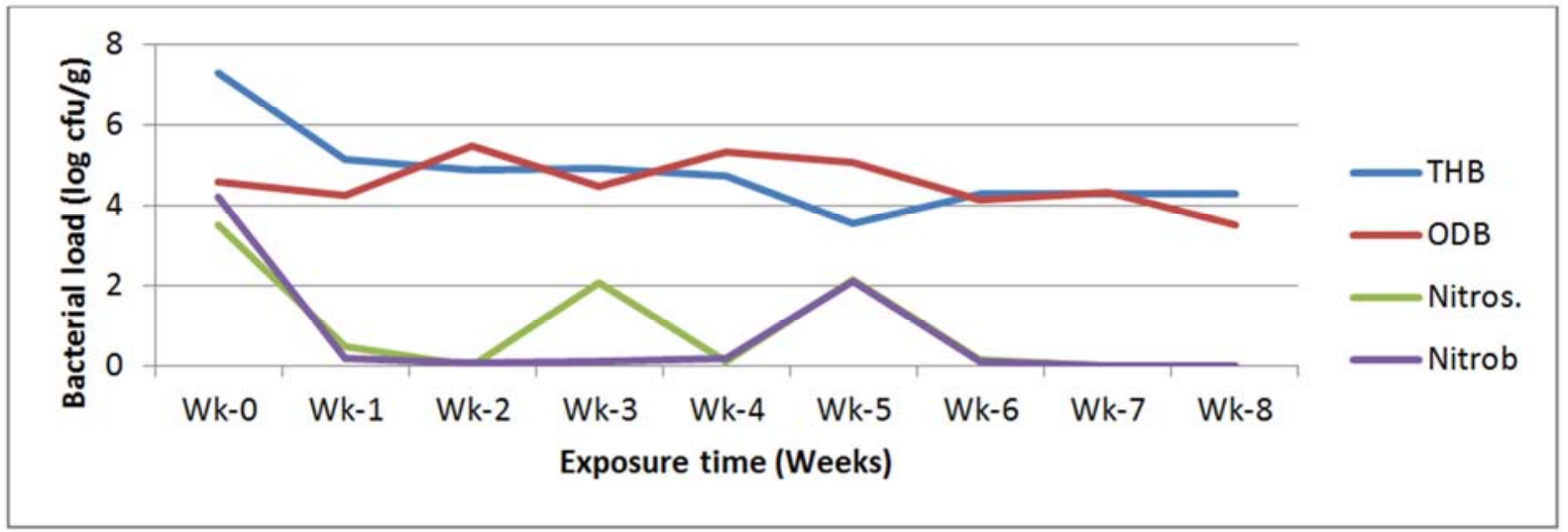

Figure 5. Changes in bacterial activities of the unpolluted (control) soil over time.

\subsection{Biodegradation of Crude Oil in Amended Soil}

Table 3 shows the estimated level of crude oil contamination of test soil and the residual loads of TPH after amendment with different levels of BSG. The residual loads of crude oil after 14 days of amendment (biodegradation) with BSG are shown in Figure 6 while the rate of degradation is illustrated in Figure 7. The rate of degradation varied with the level of contamination and amount of BSG amendment added to soil.

Table 3. The residual load and biodegradation rate of crude oil after amendment with BSG for 14 days.

\begin{tabular}{llll}
\hline Contamination & BSG Amendment level & Residual Load of TPH (mg/kg) & \% Degradation \\
\hline $2075 \mathrm{mg} / \mathrm{kg}$ & $150 \mathrm{~g} / 20 \mathrm{~kg}(0.75 \%)$ & 786.44 & 62.09 \\
& $300 \mathrm{~g} / 20 \mathrm{~kg}(1.5 \%)$ & 1136.04 & 45.25 \\
& $600 \mathrm{~g} / 20 \mathrm{~kg}(3.0 \%)$ & 1467.22 & 29.29 \\
$4150 \mathrm{mg} / \mathrm{kg}$ & $150 \mathrm{~g} / 20 \mathrm{~kg}(0.75 \%)$ & 3811.59 & 8.15 \\
& $300 \mathrm{~g} / 20 \mathrm{~kg}(1.5 \%)$ & 3401.7 & 18.03 \\
& $600 \mathrm{~g} / 20 \mathrm{~kg}(3.0 \%)$ & 3811.01 & 8.17 \\
$6225 \mathrm{mg} / \mathrm{kg}$ & $150 \mathrm{~g} / 20 \mathrm{~kg}(0.75 \%)$ & 5967.11 & 4.14 \\
& $300 \mathrm{~g} / 20 \mathrm{~kg}(1.5 \%)$ & 4963.00 & 20.27 \\
& $600 \mathrm{~g} / 20 \mathrm{~kg}(3.0 \%)$ & 4446.22 & 28.57 \\
\hline
\end{tabular}

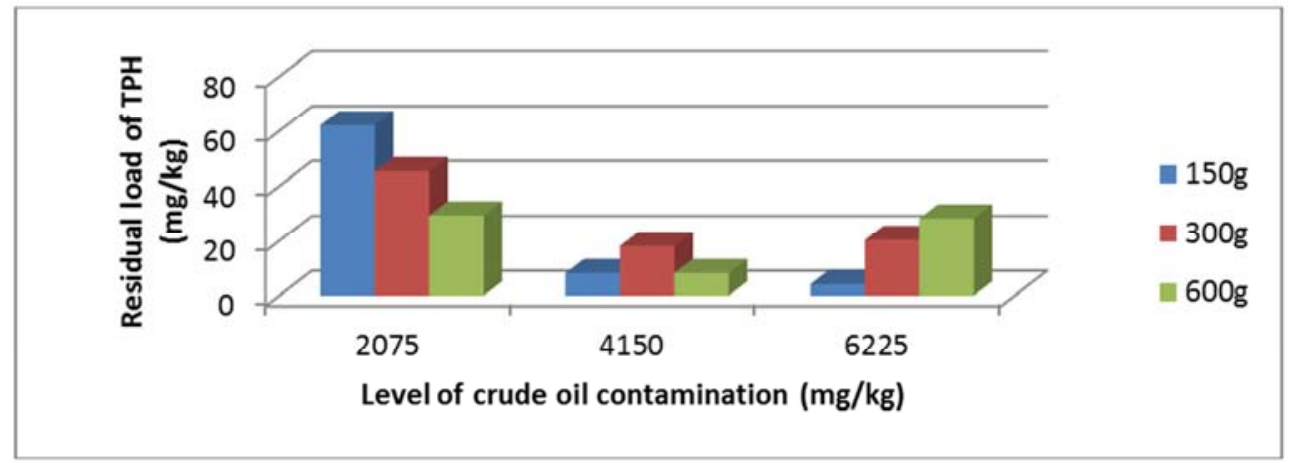

Figure 6. Residual load of TPH in soils exposed to different levels of crude oil contamination and BSG amendment for 14 days.

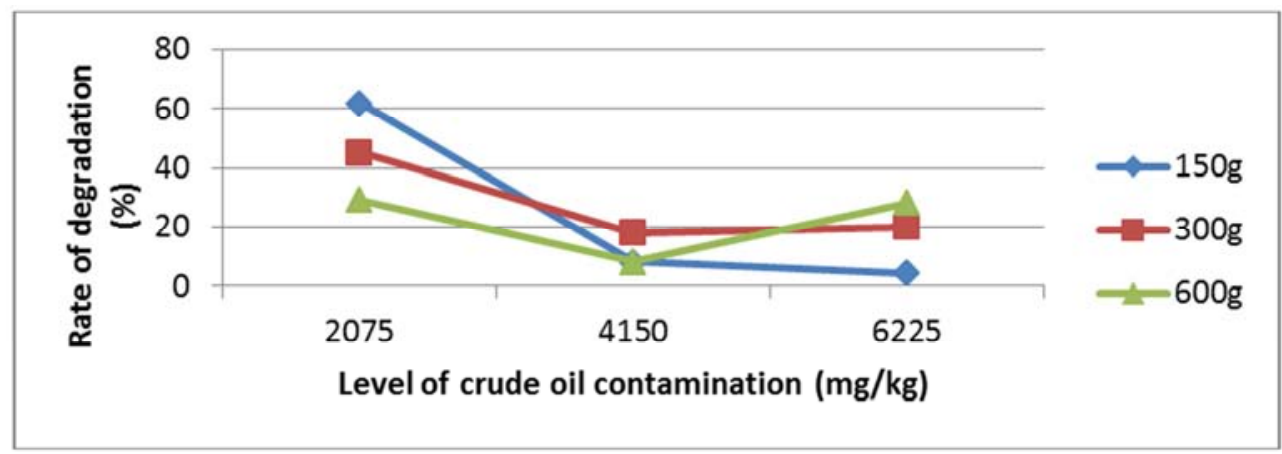

Figure 7. Rate of hydrocarbon degradation in BSG amended soil after 14 days. 


\subsection{Effects of BSG Amendment on the Growth of Pepper Cultured on Crude Oil contaminated Soil}

The results showed that BSG amendment of soil contaminated with different concentrations of the crude oil had clear but variable influence on some agronomic traits of the cultured pepper. The pepper seedlings amended with BSG were taller (Table 4) and had higher nu mbers of branches (Table 5) and leaves (Table 6). The leaves were characteristically broader (Table 7). The amendment also influences the ability to produce fruits (Table 8 ). While the untreated crop had fruit yield range of $20-45 \%, 40-65 \%$ was recorded for crop treated with BSG only and $80-100 \%$ for crops grown in BSG amended crude oil contaminated soil. The data showed that amendment of contaminated soils resulted in higher plant height, broader leaf area, higher number of leaves and branches as well as more flowers and fruits; when compared with the positive and negative controls (Table 2). It is also worthy to note that soils treated with $2075 \mathrm{mg} / \mathrm{kg}$ crude oil and amended with $150 \mathrm{~g}$ of BSG (A); $4150 \mathrm{mg} / \mathrm{kg}$ and $150 \mathrm{~g}$ (B) and; $6225 \mathrm{mg} / \mathrm{kg}$ and $150 \mathrm{~g}$ (C) greatly influenced the growth of pepper but the one with $4150 \mathrm{mg} / \mathrm{kg}$ crude oil plus $150 \mathrm{~g}$ of BSG yielded large fruits much earlier than other treatments despite fungal attack at the tail end of the research (Table 3). The fungus attacked the pepper seedlings on the 14th week (first week of January, 2016) and resulted in the withering of flowers and flower buds, leaving only one to mature to fruit. This occurred on plant exposed to $4150 \mathrm{mg} / \mathrm{kg}$ of crude oil and amended with $150 \mathrm{~g}$ of BSG. Flowering was not noticed on untreated plants (Control 2) during the course of study.

Statistical analysis has revealed the significance difference $(\mathrm{P}=0.05)$ among growth parameters of pepper seedlings cultured in treated but amended soils as compared with the growth parameters of the ones cultured on Control-1 and 2. Thus, tables 4 - 9 with some data in asterisk indicate the significance difference among treated soils with different crude oil concentrations and BSG amendments as compared with that of Control-1 as regards pepper height, number of branches, leaves, leaf area, flowers, and fruits respectively. Thus, the varied crude oil concentrations and BSG amendments supported the growth of the cultured pepper very well. For instance, table 4 with pepper seedling treated with $2075 \mathrm{mg} / \mathrm{kg}$ of crude oil amended with $150 \mathrm{~g}$ BSG has its height as $19.08 \mathrm{~cm}$ (under week - 4) as compared with control-1 (uncontaminated but amended soil) with its height as $16.50 \mathrm{~cm}$ amended with $150 \mathrm{~g}$ BSG under same week of study. This shows significance difference $(\mathrm{P}=0.05)$ in heights of pepper cultured in treated soil and the one in untreated soil under same week of study. However, some data in asterisk in tables $10-14$ uncovered the significance difference among treated soils with different crude oil concentrations and BSG amendments as compared with that of Control-2 in terms of pepper height, number of branches, leaves, leaf area, flowers and fruits respectively. In table 10 , there is also a significance difference $(\mathrm{P}=0.05)$ in height of pepper cultured in $2075 \mathrm{mg} / \mathrm{kg}$ amended with $150 \mathrm{~g}$ BSG with height of $10.75 \mathrm{~cm}$ (under week-2 of study) as compared with $7.98 \mathrm{~cm}$ height obtained in pepper cultured in soil without treatment and bioamendment under same week of study.

Therefore, from table $4-15$ there has been significance differences in growth parameters of pepper seedlings cultured in treated soils as compared with uncontaminated but amended soil (Control-1) and the soil without contaminant and amendment (Control-2) as regards height, number of branches, leaves, leaf area, flowers and fruits.

Tables below indicated the test of significance $(\mathrm{P}=0.05)$ and standard deviation of the $2075 \mathrm{mg} / \mathrm{kg} ; 4150 \mathrm{mg} / \mathrm{kg}$ and $6225 \mathrm{mg} / \mathrm{kg}$ of crude oil with BSG amendments of $150 \mathrm{~g}$, $300 \mathrm{~g}$ and $600 \mathrm{~g}$ influence on growth of pepper as compared with the Uncontaminated (Control-1).

Table 4. Height (cm) of pepper seedlings grown on soil contaminated and treated with different levels of crude oil and BSG amendment respectively.

$2075 \mathrm{mg} / \mathrm{kg}$ of crude oil.

\begin{tabular}{lllllllll}
\hline BSG & $\mathbf{0}$ & $\mathbf{2}$ & $\mathbf{4}$ & Weeks 6 & $\mathbf{8}$ & $\mathbf{1 0}$ & $\mathbf{1 2}$ & $\mathbf{1 4}$ \\
\hline $150 \mathrm{~g}$ & $8.00 \pm 0.67$ & $10.75 \pm 0.45$ & $19.08 \pm 1.69^{*}$ & $24.68 \pm 1.65$ & $30.03 \pm 1.66$ & $37.35^{ \pm} 1.86$ & $54.50 \pm 1.77$ & $58.55 \pm 1.67$ \\
$300 \mathrm{~g}$ & $7.65 \pm 0.27$ & $9.25 \pm 0.25$ & $14.65 \pm 1.54$ & $23.21 \pm 1.67$ & $56.25 \pm 1.48^{*}$ & $58.83 \pm 1.32^{*}$ & $71.30 \pm 2.05^{*}$ & $90.40 \pm 2.11^{*}$ \\
$600 \mathrm{~g}$ & $8.15 \pm 1.25$ & $9.08 \pm 1.64$ & $11.70 \pm 1.79$ & $21.74 \pm 1.72 *$ & $50.88 \pm 1.52^{*}$ & $60.73 \pm 1.90^{*}$ & $63.38 \pm 1.85^{*}$ & $66.30 \pm 1.59^{*}$ \\
\hline
\end{tabular}

$4150 \mathrm{mg} / \mathrm{kg}$ of crude oil

\begin{tabular}{lllllllll}
\hline BSG & $\mathbf{0}$ & $\mathbf{2}$ & $\mathbf{4}$ & Weeks 6 & $\mathbf{8}$ & $\mathbf{1 0}$ & $\mathbf{1 2}$ & $\mathbf{1 4}$ \\
\hline $150 \mathrm{~g}$ & $9.98 \pm 1.15^{*}$ & $11.10 \pm 1.29$ & $16.00 \pm 0.97$ & $27.64 \pm 1.94$ & $37.70 \pm 1.74^{*}$ & $48.88 \pm 1.69^{*}$ & $69.65 \pm 1.47^{*}$ & $69.35 \pm 1.68^{*}$ \\
$300 \mathrm{~g}$ & $6.73 \pm 1.09$ & $8.48 \pm 0.65$ & $13.95 \pm 1.52$ & $26.55 \pm 1.73$ & $45.40 \pm 1.47^{*}$ & $58.80 \pm 1.79^{*}$ & $60.25 \pm 1.53^{*}$ & $67.75 \pm 1.46^{*}$ \\
$600 \mathrm{~g}$ & $6.95 \pm 1.22$ & $8.88 \pm 0.89$ & $12.38 \pm 0.26$ & $18.42 \pm 1.04$ & $37.08 \pm 2.09$ & $44.33 \pm 1.79$ & $46.38 \pm 1.56$ & $52.88 \pm 1.88$ \\
\hline
\end{tabular}

$6225 \mathrm{mg} / \mathrm{kg}$ of crude oil

\begin{tabular}{lllllllll}
\hline BSG & $\mathbf{0}$ & $\mathbf{2}$ & $\mathbf{4}$ & Weeks 6 & $\mathbf{8}$ & $\mathbf{1 0}$ & $\mathbf{1 2}$ & $\mathbf{1 4}$ \\
\hline $150 \mathrm{~g}$ & $9.30 \pm 0.77$ & $11.08 \pm 0.92$ & $18.15 \pm 1.03$ & $24.80 \pm 1.70$ & $42.63 \pm 1.64^{*}$ & $57.08 \pm 1.66^{*}$ & $65.10 \pm 1.31^{*}$ & $68.00 \pm 1.70^{*}$ \\
$300 \mathrm{~g}$ & $6.65 \pm 0.43$ & $8.60 \pm 0.94$ & $13.65 \pm 1.59$ & $22.58 \pm 1.93$ & $42.83 \pm 1.95^{*}$ & $55.00 \pm 1.50^{*}$ & $69.63 \pm 1.49^{*}$ & $69.93 \pm 1.70^{*}$ \\
$600 \mathrm{~g}$ & $7.48 \pm 0.50$ & $9.30 \pm 1.33$ & $12.15 \pm 0.52$ & $16.19 \pm 1.66$ & $29.55 \pm 1.61$ & $39.35 \pm 1.45$ & $45.60 \pm 1.69$ & $56.78 \pm 1.33$ \\
\hline
\end{tabular}


Uncontaminated soil (Control 1)

\begin{tabular}{lllllllll}
\hline BSG & 0 & $\mathbf{2}$ & $\mathbf{4}$ & Weeks 6 & $\mathbf{8}$ & $\mathbf{1 0}$ & $\mathbf{1 2}$ & $\mathbf{1 4}$ \\
\hline $150 \mathrm{~g}$ & $7.93 \pm 1.32$ & $10.20 \pm 1.45$ & $16.50 \pm 1.47$ & $29.64 \pm 1.71$ & $31.88 \pm 1.82$ & $36.10 \pm 1.49$ & $56.33 \pm 1.59$ & $63.08 \pm 1.86$ \\
$300 \mathrm{~g}$ & $8.25 \pm 0.90$ & $9.10 \pm 1.10$ & $17.13 \pm 1.50$ & $25.75 \pm 1.56$ & $30.70 \pm 1.75$ & $37.63 \pm 1.72$ & $55.88 \pm 1.63$ & $57.30 \pm 1.57$ \\
$600 \mathrm{~g}$ & $8.03 \pm 0.87$ & $8.88 \pm 0.96$ & $12.40 \pm 0.40$ & $16.70 \pm 1.37$ & $44.90 \pm 1.42$ & $55.65 \pm 1.72$ & $56.38 \pm 1.63$ & $57.73 \pm 1.59$ \\
\hline
\end{tabular}

Table 5. Number of branches produced by pepper seedlings grown on soil contaminated and treated with different levels of crude oil and BSG amendment respectively.

$2075 \mathrm{mg} / \mathrm{kg}$ of crude oil

\begin{tabular}{|c|c|c|c|c|c|c|c|c|}
\hline \multirow{2}{*}{ BSG } & \multirow{2}{*}{$\mathbf{0}$} & \multirow{2}{*}{2} & \multicolumn{2}{|c|}{ Weeks } & \multirow{2}{*}{8} & \multirow[b]{2}{*}{10} & \multirow{2}{*}{12} & \multirow{2}{*}{14} \\
\hline & & & 4 & 6 & & & & \\
\hline $150 \mathrm{~g}$ & nil & Nil & nil & nil & $3 \pm 1.30$ & $6 \pm 3.67 *$ & $4 \pm 2.06$ & $5 \pm 3.90$ \\
\hline $300 \mathrm{~g}$ & nil & Nil & nil & nil & $15 \pm 6.50$ & $14 \pm 11.00 *$ & $12 \pm 8.84 *$ & $23 \pm 18.91 *$ \\
\hline $600 \mathrm{~g}$ & nil & Nil & nil & nil & $6 \pm 0.43$ & $11 \pm 4.64 *$ & $3 \pm 1.65$ & $3 \pm 5.07$ \\
\hline
\end{tabular}

$4150 \mathrm{mg} / \mathrm{kg}$ of crude oil

\begin{tabular}{lllllllll}
\hline BSG & $\mathbf{0}$ & $\mathbf{2}$ & $\mathbf{4}$ & Weeks $\mathbf{6}$ & $\mathbf{8}$ & $\mathbf{1 0}$ & $\mathbf{1 2}$ & $\mathbf{1 4}$ \\
\hline $150 \mathrm{~g}$ & nil & Nil & nil & nil & nil & Nil & $10 \pm 7.07^{*}$ & $19 \pm 13.63^{*}$ \\
$300 \mathrm{~g}$ & nil & Nil & nil & nil & nil & $1 \pm 0.43$ & $8 \pm 8.23^{*}$ & $18 \pm 9.24^{*}$ \\
$600 \mathrm{~g}$ & nil & Nil & nil & nil & nil & $2 \pm 0.87^{*}$ & $6 \pm 8.15^{*}$ & $12 \pm 10.69^{*}$ \\
\hline
\end{tabular}

$6225 \mathrm{mg} / \mathrm{kg}$ of crude oil

\begin{tabular}{lllllllll}
\hline BSG & $\mathbf{0}$ & $\mathbf{2}$ & $\mathbf{4}$ & Weeks 6 & $\mathbf{8}$ & $\mathbf{1 0}$ & $\mathbf{1 2}$ & $\mathbf{1 4}$ \\
\hline $150 \mathrm{~g}$ & nil & Nil & nil & nil & $2 \pm 0.66$ & $11 \pm 4.76^{*}$ & $14 \pm 7.18^{*}$ & $21 \pm 15.82^{*}$ \\
$300 \mathrm{~g}$ & nil & Nil & nil & nil & $2 \pm 1.09$ & $8 \pm 5.85^{*}$ & $14 \pm 13.37^{*}$ & $21 \pm 11.45^{*}$ \\
$600 \mathrm{~g}$ & nil & Nil & nil & nil & $9 \pm 4.06$ & $17 \pm 7.68^{*}$ & $5 \pm 2.86^{*}$ & $12 \pm 9.04^{*}$ \\
\hline
\end{tabular}

Comment: The pepper seedlings amended with BSG are taller, fresher, succulent, broader, longer and higher number of leaves with bigger and longer stems.

Uncontaminated Soil (Control-1).

\begin{tabular}{lllllllll}
\hline BSG & $\mathbf{0}$ & $\mathbf{2}$ & $\mathbf{4}$ & Weeks 6 & $\mathbf{8}$ & $\mathbf{1 0}$ & $\mathbf{1 2}$ & $\mathbf{1 4}$ \\
\hline $150 \mathrm{~g}$ & nil & nil & nil & nil & nil & $4 \pm 1.73$ & $7 \pm 5.12$ & $11 \pm 10.64$ \\
$300 \mathrm{~g}$ & nil & nil & nil & nil & nil & $1 \pm 0.71$ & $3 \pm 1.80$ & $8 \pm 4.74$ \\
$600 \mathrm{~g}$ & nil & nil & nil & nil & nil & $8 \pm 6.57$ & $2 \pm 1.42$ & $3 \pm 1.48$ \\
\hline
\end{tabular}

Key: nil= Not available.

Table 6. Number of leaves of pepper seedlings grown on soil contaminated and treated with different levels of crude oil and BSG amendment respectively. $2075 \mathrm{mg} / \mathrm{kg}$ of crude oil

\begin{tabular}{lllllllll}
\hline BSG & $\mathbf{0}$ & $\mathbf{2}$ & $\mathbf{4}$ & Weeks 6 & $\mathbf{8}$ & $\mathbf{1 0}$ & $\mathbf{1 2}$ & $\mathbf{1 4}$ \\
\hline $150 \mathrm{~g}$ & $6 \pm 0.43$ & $8 \pm 0.5$ & $9 \pm 1.48$ & $13 \pm 1.41$ & $16 \pm 1.66^{*}$ & $23 \pm 1.09$ & $38 \pm 1.64$ & $34 \pm 1.48$ \\
$300 \mathrm{~g}$ & $7 \pm 0.83$ & $8 \pm 0.71$ & $10 \pm 1.30^{*}$ & $14 \pm 1.48^{*}$ & $34 \pm 1.48$ & $64 \pm 1.48^{*}$ & $77 \pm 1.92^{*}$ & $93 \pm 1.64^{*}$ \\
$600 \mathrm{~g}$ & $7 \pm 1.22$ & $8 \pm 1.30$ & $11 \pm 1.5^{*}$ & $15 \pm 1.64^{*}$ & $30 \pm 1.66^{*}$ & $49 \pm 1.92^{*}$ & $24 \pm 1.64^{*}$ & $36 \pm 1.87^{*}$ \\
\hline
\end{tabular}

$4150 \mathrm{mg} / \mathrm{kg}$ of crude oil

\begin{tabular}{lllllllll}
\hline BSG & $\mathbf{0}$ & $\mathbf{2}$ & $\mathbf{4}$ & Weeks 6 & $\mathbf{8}$ & $\mathbf{1 0}$ & $\mathbf{1 2}$ & $\mathbf{1 4}$ \\
\hline $150 \mathrm{~g}$ & $7 \pm 1.83$ & $8 \pm 0.71$ & $11 \pm 1.73^{*}$ & $15.00 \pm 1.00$ & $16.00 \pm 1.22^{*}$ & $22.00 \pm 1.66$ & $64.00 \pm 1.5^{*}$ & $64.00 \pm 1.66$ \\
$300 \mathrm{~g}$ & $7.00 \pm 1.09$ & $8.00 \pm 1.09$ & $10.00 \pm 1.41^{*}$ & $15.00 \pm 1.5^{*}$ & $28.00 \pm 1.79^{*}$ & $53.00 \pm 1.64^{*}$ & $51.00 \pm 1.5^{*}$ & $59.00 \pm 1.64^{*}$ \\
$600 \mathrm{~g}$ & $6.00 \pm 0.83$ & $7.00 \pm 0.87$ & $9.00 \pm 1.09$ & $12.00 \pm 1.79^{*}$ & $21.00 \pm 1.66$ & $22.00 \pm 1.58$ & $35.00 \pm 1.64^{*}$ & $45.00 \pm 1.5^{*}$ \\
\hline
\end{tabular}

$6225 \mathrm{mg} / \mathrm{kg}$ of crude oil

\begin{tabular}{lllllllll}
\hline BSG & $\mathbf{0}$ & $\mathbf{2}$ & $\mathbf{4}$ & Weeks 6 & $\mathbf{8}$ & $\mathbf{1 0}$ & $\mathbf{1 2}$ & $\mathbf{1 4}$ \\
\hline $150 \mathrm{~g}$ & $7.00 \pm 0.83$ & $8.00 \pm 1.30$ & $10.00 \pm 0.43^{*}$ & $15.00 \pm 1.30$ & $29.00 \pm 1.5^{*}$ & $53.00 \pm 1.48^{*}$ & $67.00 \pm 1.73^{*}$ & $60.00 \pm 1.58$ \\
$300 \mathrm{~g}$ & $7.00 \pm 0.83$ & $8.00 \pm 1.09$ & $10.00 \pm 0.86^{*}$ & $15.00 \pm 1.5^{*}$ & $24.00 \pm 1.5^{*}$ & $57.00 \pm 1.64^{*}$ & $102.00 \pm 1.58^{*}$ & $103.00 \pm 1.64^{*}$ \\
$600 \mathrm{~g}$ & $6.00 \pm 0.83$ & $8.00 \pm 0.83$ & $9.00 \pm 1.00$ & $13.00 \pm 1.5^{*}$ & $18.00 \pm 2.00$ & $32.00 \pm 1.48$ & $39.00 \pm 1.73^{*}$ & $56.00 \pm 1.58^{*}$ \\
\hline \multicolumn{2}{l}{ Uncontaminated Soil (Control-1). } & & & & & & \\
\hline BSG & $\mathbf{0}$ & $\mathbf{2}$ & $\mathbf{4}$ & Weeks 6 & $\mathbf{8}$ & $\mathbf{1 0}$ & $\mathbf{1 2}$ & \\
\hline $150 \mathrm{~g}$ & $7.00 \pm 1.12$ & $8.00 \pm 1.12$ & $8.00 \pm 1.48$ & $16.00 \pm 1.66$ & $13.00 \pm 1.48$ & $22.00 \pm 1.48$ & $50.00 \pm 1.92$ & $66.00 \pm 1.64$ \\
$300 \mathrm{~g}$ & $6.00 \pm 0.71$ & $7.00 \pm 0.71$ & $8.00 \pm 1.48$ & $12.00 \pm 1.66$ & $15.00 \pm 1.79$ & $19.00 \pm 1.5$ & $33.00 \pm 1.5$ & $30.00 \pm 1.79$ \\
$600 \mathrm{~g}$ & $6.00 \pm 0.43$ & $7.00 \pm 0.71$ & $8.00 \pm 1.22$ & $10.00 \pm 0.83$ & $24.00 \pm 1.48$ & $41.00 \pm 1.64$ & $22.00 \pm 1.64$ & $34.00 \pm 1.64$ \\
\hline
\end{tabular}


Table 7. Leaf area $\left(\mathrm{cm}^{2}\right)$ of pepper seedlings grown on soil contaminated and treated with different levels of crude oil and BSG amendment respectively. $2075 \mathrm{mg} / \mathrm{kg}$ of crude oil

\begin{tabular}{lllllllll}
\hline BSG & 0 & $\mathbf{2}$ & $\mathbf{4}$ & Weeks 6 & $\mathbf{8}$ & $\mathbf{1 0}$ & $\mathbf{1 2}$ & $\mathbf{1 4}$ \\
\hline $150 \mathrm{~g}$ & $8.46 \pm 2.54$ & $16.00 \pm 5.20$ & $46.17 \pm 8.40$ & $60.95 \pm 10.39$ & $101.47 \pm 32.69^{*}$ & $122.78 \pm 44.61$ & $158.42 \pm 30.17^{*}$ & $145.66 \pm 17.46$ \\
$300 \mathrm{~g}$ & $9.09 \pm 2.38$ & $17.09 \pm 6.69^{*}$ & $58.32 \pm 26.77$ & $70.32 \pm 43.18$ & $129.70 \pm 49.96^{*}$ & $149.15 \pm 54.39^{*}$ & $155.85 \pm 7.25$ & $173.55 \pm 55.24^{*}$ \\
$600 \mathrm{~g}$ & $6.96 \pm 2.55$ & $11.07 \pm 6.52$ & $36.11 \pm 28.51$ & $60.19 \pm 34.39^{*}$ & $149.24 \pm 32.20^{*}$ & $188.48 \pm 54.20^{*}$ & $150.18 \pm 15.69$ & $143.42 \pm 42.55$ \\
\hline
\end{tabular}

$4150 \mathrm{mg} / \mathrm{kg}$ of crude oil

\begin{tabular}{lllllllll}
\hline BSG & $\mathbf{0}$ & $\mathbf{2}$ & $\mathbf{4}$ & Weeks 6 & $\mathbf{8}$ & $\mathbf{1 0}$ & $\mathbf{1 2}$ & $\mathbf{1 4}$ \\
\hline $150 \mathrm{~g}$ & $8.23 \pm 2.54$ & $14.98 \pm 6.36$ & $73.41 \pm 24.59^{*}$ & $91.83 \pm 31.47^{*}$ & $90.81 \pm 24.12$ & $149.75 \pm 13.01^{*}$ & $169.62 \pm 38.98^{*}$ & $202.47 \pm 14.50^{*}$ \\
$300 \mathrm{~g}$ & $7.51 \pm 3.22$ & $14.19 \pm 5.94$ & $69.96 \pm 20.37^{*}$ & $88.31 \pm 24.38^{*}$ & $107.51 \pm 61.60$ & $173.46 \pm 58.84^{*}$ & $142.54 \pm 13.52$ & $138.16 \pm 38.78$ \\
$600 \mathrm{~g}$ & $7.32 \pm 2.90$ & $16.21 \pm 3.96^{*}$ & $66.85 \pm 30.83^{*}$ & $64.86 \pm 25.43^{*}$ & $87.81 \pm 60.81$ & $130.58 \pm 39.66$ & $141.85 \pm 34.08$ & $152.36 \pm 38.57$ \\
\hline
\end{tabular}

$6225 \mathrm{mg} / \mathrm{kg}$ of crude oil

\begin{tabular}{lllllllll}
\hline BSG & $\mathbf{0}$ & $\mathbf{2}$ & $\mathbf{4}$ & Weeks 6 & $\mathbf{8}$ & $\mathbf{1 0}$ & $\mathbf{1 2}$ & $\mathbf{1 4}$ \\
\hline $150 \mathrm{~g}$ & $10.97 \pm 4.07$ & $14.93 \pm 4.64$ & $77.57 \pm 14.90^{*}$ & $90.76 \pm 24.94^{*}$ & $143.41 \pm 18.29^{*}$ & $152.39 \pm 27.30^{*}$ & $160.96 \pm 38.92^{*}$ & $174.47 \pm 53.52^{*}$ \\
$300 \mathrm{~g}$ & $8.89 \pm 3.45$ & $12.20 \pm 5.39$ & $56.12 \pm 10.96$ & $80.22 \pm 12.78$ & $135.21 \pm 28.28^{*}$ & $176.13 \pm 55.19^{*}$ & $169.19 \pm 17.27^{*}$ & $167.30 \pm 22.71$ \\
$600 \mathrm{~g}$ & $12.22 \pm 3.95^{*}$ & $11.73 \pm 8.81$ & $71.99 \pm 4.17^{*}$ & $70.70 \pm 22.74^{*}$ & $123.56 \pm 41.88$ & $125.69 \pm 44.96$ & $167.90 \pm 17.00^{*}$ & $173.25 \pm 54.10^{*}$ \\
\hline
\end{tabular}

Uncontaminated Soil (Control-1).

\begin{tabular}{lllllllll}
\hline BSG & $\mathbf{0}$ & $\mathbf{2}$ & $\mathbf{4}$ & Weeks 6 & $\mathbf{8}$ & $\mathbf{1 0}$ & $\mathbf{1 2}$ & $\mathbf{1 4}$ \\
\hline $150 \mathrm{~g}$ & $9.94 \pm 3.20$ & $16.94 \pm 11.01$ & $52.19 \pm 17.10$ & $78.60 \pm 22.29$ & $98.88 \pm 31.71$ & $130.90 \pm 34.29$ & $155.71 \pm 12.64$ & $162.71 \pm 38.02$ \\
$300 \mathrm{~g}$ & $7.24 \pm 2.79$ & $13.85 \pm 9.28$ & $65.10 \pm 17.86$ & $81.42 \pm 31.63$ & $107.00 \pm 32.23$ & $112.98 \pm 43.30$ & $165.96 \pm 32.07$ & $165.94 \pm 47.30$ \\
$600 \mathrm{~g}$ & $9.25 \pm 3.55$ & $12.30 \pm 2.49$ & $35.78 \pm 8.91$ & $46.59 \pm 9.97$ & $134.86 \pm 44.08$ & $175.67 \pm 53.99$ & $154.89 \pm 29.01$ & $158.94 \pm 28.65$ \\
\hline
\end{tabular}

Leaf area (LA) was determined by multiplying leaf length by leaf width with the correction coefficient (r) which is 0.72 as proposed by Adesua (2014) [6] Leaf Area was calculated thus: LA = L X W X r

Table 8. Number of flowers of pepper seedlings grown on soil contaminated and treated with different levels of crude oil and BSG amendment respectively.

$2075 \mathrm{mg} / \mathrm{kg}$ of crude oil

\begin{tabular}{lllllllll}
\hline BSG & $\mathbf{0}$ & $\mathbf{2}$ & $\mathbf{4}$ & Weeks 6 & $\mathbf{8}$ & $\mathbf{1 0}$ & $\mathbf{1 2}$ & 14 \\
\hline $150 \mathrm{~g}$ & nil & nil & nil & nil & Nil & Nil & Nil & Nil \\
$300 \mathrm{~g}$ & nil & nil & nil & nil & Nil & Nil & Nil & Nil \\
$600 \mathrm{~g}$ & nil & nil & nil & nil & Nil & 3 Real F. \& 31 F. Buds $\pm 8.44 *$ & Nil & Nil \\
\hline
\end{tabular}

$4150 \mathrm{mg} / \mathrm{kg}$ of crude oil

\begin{tabular}{lllllllll}
\hline BSG & $\mathbf{0}$ & $\mathbf{2}$ & $\mathbf{4}$ & Weeks $\mathbf{6}$ & $\mathbf{8}$ & $\mathbf{1 0}$ & $\mathbf{1 2}$ & 14 \\
\hline $150 \mathrm{~g}$ & nil & nil & nil & nil & Nil & Nil & 20 Real F. $\pm 8.38^{*}$ & Nil \\
$300 \mathrm{~g}$ & nil & nil & nil & nil & Nil & Nil & Nil & Nil \\
$600 \mathrm{~g}$ & nil & nil & nil & nil & Nil & Nil & Nil & Nil \\
\hline
\end{tabular}

$6225 \mathrm{mg} / \mathrm{kg}$ of crude oil

\begin{tabular}{|c|c|c|c|c|c|c|c|c|}
\hline BSG & $\mathbf{0}$ & 2 & 4 & Weeks 6 & 8 & 10 & 12 & 14 \\
\hline $150 \mathrm{~g}$ & nil & nil & Nil & nil & Nil & Nil & Nil & F. Buds $6.00 \pm 2.06^{*}$ \\
\hline $300 \mathrm{~g}$ & nil & nil & Nil & nil & F. Buds $5.00 \pm 2.17^{*}$ & Nil & Real F. $40.00 \pm 17.32 *$ & Nil \\
\hline $600 \mathrm{~g}$ & nil & nil & Nil & nil & F. Buds $3.00 \pm 1.30 *$ & F. Buds $8.00 \pm 3.46^{*}$ & Nil & Nil \\
\hline
\end{tabular}

Comment: A fungus attacked the pepper seedlings on the first week of January, 2016. The fungus withered and detached all the flowers, leaving only one that gave birth to one surviving fruit [the seedling planted on wooden microcosm contaminated with $4150 \mathrm{mg} / \mathrm{kg}$ Crude oil and amended with $150 \mathrm{~g}$ BSG]. Key: nil $=$ No flower(s); while F. Buds = flower buds and Real F. $=$ real flower.

Uncontaminated Soil (Control-1).

\begin{tabular}{lllllllll}
\hline BSG & $\mathbf{0}$ & $\mathbf{2}$ & $\mathbf{4}$ & Weeks $\mathbf{6}$ & $\mathbf{8}$ & $\mathbf{1 0}$ & $\mathbf{1 2}$ & Nil \\
\hline 150BSG & nil & nil & nil & nil & Nil & Nil & 11 Real F. $\pm 4.76^{*}$ & Nil \\
$300 \mathrm{~g}$ & nil & nil & nil & nil & Nil & Nil & nil & Nil \\
$600 \mathrm{~g}$ & nil & nil & nil & nil & Nil & Nil & nil & \\
\hline
\end{tabular}


Table 9. Number of fruits of pepper seedlings grown on soil contaminated and treated with different levels of crude oil and BSG amendment respectively. $2075 \mathrm{mg} / \mathrm{kg}$ of crude oil.

\begin{tabular}{lllllllll}
\hline BSG & $\mathbf{0}$ & $\mathbf{2}$ & $\mathbf{4}$ & Weeks 6 & $\mathbf{8}$ & $\mathbf{1 0}$ & $\mathbf{1 2}$ & $\mathbf{1 4}$ \\
\hline $150 \mathrm{~g}$ & nil & Nil & nil & nil & nil & Nil & Nil & Nil \\
$300 \mathrm{~g}$ & nil & Nil & nil & nil & nil & Nil & Nil & Nil \\
$600 \mathrm{~g}$ & nil & Nil & nil & nil & nil & Nil & Nil & Nil \\
\hline
\end{tabular}

$4150 \mathrm{mg} / \mathrm{kg}$ of crude oil

\begin{tabular}{lllllllll}
\hline BSG & $\mathbf{0}$ & $\mathbf{2}$ & $\mathbf{4}$ & Weeks $\mathbf{6}$ & $\mathbf{8}$ & $\mathbf{1 0}$ & $\mathbf{1 2}$ & $\mathbf{1 4}$ \\
\hline $150 \mathrm{~g}$ & nil & nil & nil & Nil & nil & nil & Nil & 1 \\
$300 \mathrm{~g}$ & nil & nil & nil & Nil & nil & nil & Nil & Nil \\
$600 \mathrm{~g}$ & nil & nil & nil & Nil & nil & nil & Nil & Nil \\
\hline
\end{tabular}

Note: Only one of the pepper seedlings planted on microcosm contaminated with $0.416 \%$ Crude oil and amended with $0.75 \%$ BSG produced one fruit out of all seedlings that bore flowers. This was due to the fungal attack in that all other flowers withered and fell-off.

$6225 \mathrm{mg} / \mathrm{kg}$ of crude oil

\begin{tabular}{lllllllll}
\hline BSG & $\mathbf{0}$ & $\mathbf{2}$ & $\mathbf{4}$ & Weeks $\mathbf{6}$ & $\mathbf{8}$ & $\mathbf{1 0}$ & $\mathbf{1 2}$ & $\mathbf{1 4}$ \\
\hline $150 \mathrm{~g}$ & nil & nil & nil & Nil & nil & nil & Nil & Nil \\
$300 \mathrm{~g}$ & nil & nil & nil & Nil & nil & nil & Nil & Nil \\
$600 \mathrm{~g}$ & nil & nil & nil & Nil & nil & nil & Nil & Nil \\
\hline
\end{tabular}

Key: nil $=$ No fruit

Uncontaminated Soil (Control-1).

\begin{tabular}{lllllllll}
\hline BSG & $\mathbf{0}$ & $\mathbf{2}$ & $\mathbf{4}$ & Weeks $\mathbf{6}$ & $\mathbf{8}$ & $\mathbf{1 0}$ & $\mathbf{1 2}$ & $\mathbf{1 4}$ \\
\hline $150 \mathrm{~g}$ & nil & nil & nil & nil & nil & nil & Nil & Nil \\
$300 \mathrm{~g}$ & nil & nil & nil & nil & nil & nil & Nil & Nil \\
$600 \mathrm{~g}$ & nil & nil & nil & nil & nil & nil & Nil & Nil \\
\hline
\end{tabular}

Note: Asterisks $(*)$ shows significance difference $(\mathrm{P}=0.05)$.

Tables below indicated the test of significance $(\mathrm{P}=0.05)$ and standard deviation of the $2075 \mathrm{mg} / \mathrm{kg} ; 4150 \mathrm{mg} / \mathrm{kg}$ and $6225 \mathrm{mg} / \mathrm{kg}$ of crude oil with BSG amendments of $150 \mathrm{~g}, 300 \mathrm{~g}$ and $600 \mathrm{~g}$ influence on growth of pepper as compared with the Uncontaminated and Un-amended soil ( Control-2).

Table 10. Height of pepper seedlings grown on soil contaminated and treated with different levels of crude oil and BSG amendment respectively. $2075 \mathrm{mg} / \mathrm{kg}$ of crude oil.

\begin{tabular}{lllllllll}
\hline BSG & $\mathbf{0}$ & $\mathbf{2}$ & $\mathbf{4}$ & Weeks 6 & $\mathbf{8}$ & $\mathbf{1 0}$ & $\mathbf{1 2}$ & $\mathbf{1 4}$ \\
\hline $150 \mathrm{~g}$ & $8.00 \pm 0.67$ & $10.75 \pm 0.45^{*}$ & $19.08 \pm 1.69^{*}$ & $24.68 \pm 1.65^{*}$ & $30.03 \pm 1.66^{*}$ & $37.35^{ \pm} 1.86^{*}$ & $54.50 \pm 1.77^{*}$ & $58.55 \pm 1.67^{*}$ \\
$300 \mathrm{~g}$ & $7.65 \pm 0.27$ & $9.25 \pm 0.25$ & $14.65 \pm 1.54^{*}$ & $23.21 \pm 1.67^{*}$ & $56.25 \pm 1.48^{*}$ & $58.83 \pm 1.32^{*}$ & $71.30 \pm 2.05^{*}$ & $90.40 \pm 2.11^{*}$ \\
$600 \mathrm{~g}$ & $8.15 \pm 1.25$ & $9.08 \pm 1.64$ & $11.70 \pm 1.79$ & $21.74 \pm 1.72^{*}$ & $50.88 \pm 1.52^{*}$ & $60.73 \pm 1.90^{*}$ & $63.38 \pm 1.85^{*}$ & $66.30 \pm 1.59^{*}$ \\
\hline
\end{tabular}

$4150 \mathrm{mg} / \mathrm{kg}$ of crude oil

\begin{tabular}{lllllllll}
\hline BSG & $\mathbf{0}$ & $\mathbf{2}$ & $\mathbf{4}$ & Weeks 6 & $\mathbf{8}$ & $\mathbf{1 0}$ & $\mathbf{1 2}$ & $\mathbf{1 4}$ \\
\hline $150 \mathrm{~g}$ & $9.98 \pm 1.15^{*}$ & $11.10 \pm 1.29^{*}$ & $16.00 \pm 0.97^{*}$ & $27.64 \pm 1.94^{*}$ & $37.70 \pm 1.74^{*}$ & $48.88 \pm 1.69^{*}$ & $69.65 \pm 1.47^{*}$ & $69.35 \pm 1.68^{*}$ \\
$300 \mathrm{~g}$ & $6.73 \pm 1.09$ & $8.48 \pm 0.65$ & $13.95 \pm 1.52^{*}$ & $26.55 \pm 1.73^{*}$ & $45.40 \pm 1.47^{*}$ & $58.80 \pm 1.79^{*}$ & $60.25 \pm 1.53^{*}$ & $67.75 \pm 1.46^{*}$ \\
$600 \mathrm{~g}$ & $6.95 \pm 1.22$ & $8.88 \pm 0.89$ & $12.38 \pm 0.26$ & $18.42 \pm 1.04^{*}$ & $37.08 \pm 2.09^{*}$ & $44.33 \pm 1.79^{*}$ & $46.38 \pm 1.56^{*}$ & $52.88 \pm 1.88^{*}$ \\
\hline
\end{tabular}

$6225 \mathrm{mg} / \mathrm{kg}$ of crude oil

\begin{tabular}{lllllllll}
\hline BSG & $\mathbf{0}$ & $\mathbf{2}$ & $\mathbf{4}$ & Weeks 6 & $\mathbf{8}$ & $\mathbf{1 0}$ & $\mathbf{1 2}$ & $\mathbf{1 4}$ \\
\hline $150 \mathrm{~g}$ & $9.30 \pm 0.77^{*}$ & $11.08 \pm 0.92^{*}$ & $18.15 \pm 1.03^{*}$ & $24.80 \pm 1.70^{*}$ & $42.63 \pm 1.64^{*}$ & $57.08 \pm 1.66^{*}$ & $65.10 \pm 1.31^{*}$ & $68.00 \pm 1.70^{*}$ \\
$300 \mathrm{~g}$ & $6.65 \pm 0.43$ & $8.60 \pm 0.94$ & $13.65 \pm 1.59^{*}$ & $22.58 \pm 1.93^{*}$ & $42.83 \pm 1.95^{*}$ & $55.00 \pm 1.50^{*}$ & $69.63 \pm 1.49^{*}$ & $69.93 \pm 1.70^{*}$ \\
$600 \mathrm{~g}$ & $7.48 \pm 0.50$ & $9.30 \pm 1.33$ & $12.15 \pm 0.52$ & $16.19 \pm 1.66^{*}$ & $29.55 \pm 1.61^{*}$ & $39.35 \pm 1.45^{*}$ & $45.60 \pm 1.69^{*}$ & $56.78 \pm 1.33^{*}$ \\
\hline
\end{tabular}

Uncontaminated and un-amended (Control 2)

\begin{tabular}{lllllllll}
\hline & $\mathbf{0}$ & $\mathbf{2}$ & $\mathbf{4}$ & $\mathbf{6}$ & $\mathbf{8}$ & $\mathbf{1 0}$ & $\mathbf{1 2}$ & $\mathbf{1 4}$ \\
\hline Untreated Seedling & $7.00 \pm 0.9$ & $7.98 \pm 0.94$ & $11.50 \pm 1.51$ & $12.15 \pm 2.05$ & $15.60 \pm 1.71$ & $27.40 \pm 1.92$ & $18.63 \pm 1.56$ & $19.63 \pm 1.71$ \\
\hline
\end{tabular}


Table 11. Number of branches produced by pepper seedlings grown on soil contaminated and treated with different levels of crude oil and BSG amendment respectively.

$2075 \mathrm{mg} / \mathrm{kg}$ of crude oil

\begin{tabular}{|c|c|c|c|c|c|c|c|c|}
\hline BSG & $\mathbf{0}$ & 2 & 4 & Weeks 6 & 8 & 10 & 12 & 14 \\
\hline $50 \mathrm{~g}$ & nil & nil & Nil & Nil & $3 \pm 1.30^{*}$ & $6 \pm 3.67^{*}$ & $4 \pm 2.06^{*}$ & $5 \pm 3.90^{*}$ \\
\hline $300 \mathrm{~g}$ & nil & nil & Nil & Nil & $15 \pm 6.50 *$ & $14 \pm 11.00^{*}$ & $12 \pm 8.84 *$ & $23 \pm 18.91 *$ \\
\hline $600 \mathrm{~g}$ & nil & nil & Nil & Nil & $6 \pm 0.43^{*}$ & $11 \pm 4.64 *$ & $3 \pm 1.65^{*}$ & $3 \pm 5.07 *$ \\
\hline
\end{tabular}

$4150 \mathrm{mg} / \mathrm{kg}$ of crude oil

\begin{tabular}{lllllllll}
\hline BSG & $\mathbf{0}$ & $\mathbf{2}$ & $\mathbf{4}$ & Weeks 6 & $\mathbf{8}$ & $\mathbf{1 0}$ & $\mathbf{1 2}$ \\
\hline $150 \mathrm{~g}$ & nil & nil & Nil & Nil & nil & Nil & $10 \pm 7.07^{*}$ & $19 \pm 13.63^{*}$ \\
$300 \mathrm{~g}$ & nil & nil & Nil & Nil & nil & $1 \pm 0.43$ & $8 \pm 8.23^{*}$ \\
$600 \mathrm{~g}$ & nil & nil & Nil & Nil & nil & $2 \pm 0.87^{*}$ & $6 \pm 8.15^{*}$ \\
\hline
\end{tabular}

$6225 \mathrm{mg} / \mathrm{kg}$ of crude oil

\begin{tabular}{|c|c|c|c|c|c|c|c|c|}
\hline BSG & $\mathbf{0}$ & 2 & 4 & Weeks 6 & 8 & 10 & 12 & 14 \\
\hline $150 \mathrm{~g}$ & nil & nil & Nil & Nil & $2 \pm 0.66^{*}$ & $11 \pm 4.76^{*}$ & $14 \pm 7.18^{*}$ & $21 \pm 15.82 *$ \\
\hline $300 \mathrm{~g}$ & nil & nil & Nil & Nil & $2 \pm 1.09 *$ & $8 \pm 5.85^{*}$ & $14 \pm 13.37^{*}$ & $21 \pm 11.45^{*}$ \\
\hline
\end{tabular}

Comment: The pepper seedlings amended with BSG are taller, fresher, succulent, broader, longer and higher number of leaves with bigger and longer stems.

Uncontaminated and un-amended Soil (Control 2)

\begin{tabular}{llllllll}
\hline & $\mathbf{0}$ & $\mathbf{2}$ & $\mathbf{4}$ & $\mathbf{6}$ & $\mathbf{8}$ & $\mathbf{1 0}$ & $\mathbf{1 2}$ \\
\hline Number of Branches & nil & Nil & Nil & Nil & Nil & Nil & nil \\
\hline
\end{tabular}

Key: nil= Not available.

Table 12. Number of leaves of pepper seedlings grown on soil contaminated and treated with different levels of crude oil and BSG amendment respectively. $2075 \mathrm{mg} / \mathrm{kg}$ of crude oil

\begin{tabular}{|c|c|c|c|c|c|c|c|c|}
\hline BSG & $\mathbf{0}$ & 2 & 4 & Weeks 6 & 8 & 10 & 12 & 14 \\
\hline $150 \mathrm{~g}$ & $6 \pm 0.43$ & $8 \pm 0.5^{*}$ & $9 \pm 1.48$ & $13 \pm 1.41 *$ & $16 \pm 1.66^{*}$ & $23 \pm 1.09 *$ & $38 \pm 1.64 *$ & $34 \pm 1.48 *$ \\
\hline $300 \mathrm{~g}$ & $7 \pm 0.83 *$ & $8 \pm 0.71 *$ & $10 \pm 1.30 *$ & $14 \pm 1.48 *$ & $34 \pm 1.48 *$ & $64 \pm 1.48 *$ & $77 \pm 1.92 *$ & $93 \pm 1.64 *$ \\
\hline $600 \mathrm{~g}$ & $7 \pm 1.22 *$ & $8 \pm 1.30 *$ & $11 \pm 1.5^{*}$ & $15 \pm 1.64 *$ & $30 \pm 1.66^{*}$ & $49 \pm 1.92 *$ & $24 \pm 1.64 *$ & $36 \pm 1.87 *$ \\
\hline
\end{tabular}

$4150 \mathrm{mg} / \mathrm{kg}$ of crude oil

\begin{tabular}{|c|c|c|c|c|c|c|c|c|}
\hline BSG & 0 & 2 & 4 & Weeks 6 & 8 & 10 & 12 & 14 \\
\hline $150 \mathrm{~g}$ & $7 \pm 1.83^{*}$ & $8 \pm 0.71 *$ & $11 \pm 1.73 *$ & $15.00 \pm 1.00 *$ & $16.00 \pm 1.22 *$ & $22.00 \pm 1.66^{*}$ & $64.00 \pm 1.5^{*}$ & $64.00 \pm 1.66^{*}$ \\
\hline $300 \mathrm{~g}$ & $7.00 \pm 1.09 *$ & $8.00 \pm 1.09 *$ & $10.00 \pm 1.41 *$ & $15.00 \pm 1.5^{*}$ & $28.00 \pm 1.79 *$ & $53.00 \pm 1.64 *$ & $51.00 \pm 1.5^{*}$ & $59.00 \pm 1.64 *$ \\
\hline $600 \mathrm{~g}$ & $6.00 \pm 0.83$ & $7.00 \pm 0.87$ & $9.00 \pm 1.09$ & $12.00 \pm 1.79 *$ & $21.00 \pm 1.66^{*}$ & $22.00 \pm 1.58 *$ & $35.00 \pm 1.64 *$ & $45.00 \pm 1.5 *$ \\
\hline
\end{tabular}

$6225 \mathrm{mg} / \mathrm{kg}$ of crude oil

\begin{tabular}{|c|c|c|c|c|c|c|c|c|}
\hline BSG & $\mathbf{0}$ & 2 & 4 & Weeks 6 & 8 & 10 & 12 & 14 \\
\hline $150 \mathrm{~g}$ & $7.00 \pm 0.83 *$ & $8.00 \pm 1.30 *$ & $10.00 \pm 0.43^{*}$ & $15.00 \pm 1.30 *$ & $29.00 \pm 1.5^{*}$ & $53.00 \pm 1.48^{*}$ & $67.00 \pm 1.73^{*}$ & $60.00 \pm 1.58^{*}$ \\
\hline $300 \mathrm{~g}$ & $7.00 \pm 0.83 *$ & $8.00 \pm 1.09 *$ & $10.00 \pm 0.86^{*}$ & $15.00 \pm 1.5^{*}$ & $24.00 \pm 1.5 *$ & $57.00 \pm 1.64 *$ & $102.00 \pm 1.58 *$ & $103.00 \pm 1.64 *$ \\
\hline $600 \mathrm{~g}$ & $6.00 \pm 0.83$ & $8.00 \pm 0.83^{*}$ & $9.00 \pm 1.00$ & $13.00 \pm 1.5^{*}$ & $18.00 \pm 2.00 *$ & $32.00 \pm 1.48^{*}$ & $39.00 \pm 1.73 *$ & $56.00 \pm 1.58^{*}$ \\
\hline
\end{tabular}

Uncontaminated and un-amended Soil (Control-2).

\begin{tabular}{llllllll}
\hline & $\mathbf{0}$ & $\mathbf{2}$ & $\mathbf{4}$ & $\mathbf{6}$ & $\mathbf{8}$ & $\mathbf{1 0}$ & $\mathbf{1 2}$ \\
\hline Number of Leaves & $5.00 \pm 1.09$ & $6.00 \pm 1.09$ & $8.00 \pm 1.5$ & $10.00 \pm 1.5$ & $11.00 \pm 1.22$ & $11.00 \pm 1.48$ & $13.00 \pm 1.73$ \\
\hline
\end{tabular}

Table 13. Leaf area $\left(\mathrm{cm}^{2}\right)$ of pepper seedlings grown on soil contaminated and treated with different levels of crude oil and BSG amendment respectively. $2075 \mathrm{mg} / \mathrm{kg}$ of crude oil

\begin{tabular}{|c|c|c|c|c|c|c|c|c|}
\hline BSG & 0 & 2 & 4 & Weeks 6 & 8 & 10 & 12 & 14 \\
\hline $150 \mathrm{~g}$ & $8.46 \pm 2.54$ & $16.00 \pm 5.20 *$ & $46.17 \pm 8.40^{*}$ & $60.95 \pm 10.39 *$ & $101.47 \pm 32.69 *$ & $122.78 \pm 44.61 *$ & $158.42 \pm 30.17 *$ & $145.66 \pm 17.46^{*}$ \\
\hline $300 \mathrm{~g}$ & $9.09 \pm 2.38$ & $17.09 \pm 6.69 *$ & $58.32 \pm 26.77^{*}$ & $70.32 \pm 43.18^{*}$ & $129.70 \pm 49.96^{*}$ & $149.15 \pm 54.39 *$ & $155.85 \pm 7.25^{*}$ & $173.55 \pm 55.24 *$ \\
\hline $600 \mathrm{~g}$ & $6.96 \pm 2.55$ & $11.07 \pm 6.52 *$ & $36.11 \pm 28.51 *$ & $60.19 \pm 34.39 *$ & $149.24 \pm 32.20$ & $188.48 \pm 54.20 *$ & $150.18 \pm 15.69 *$ & $143.42 \pm 42.55^{*}$ \\
\hline
\end{tabular}


$4150 \mathrm{mg} / \mathrm{kg}$ of crude oil

\begin{tabular}{lllllllll}
\hline BSG & $\mathbf{0}$ & $\mathbf{2}$ & $\mathbf{4}$ & Weeks 6 & $\mathbf{8}$ & $\mathbf{1 0}$ & $\mathbf{1 2}$ & $\mathbf{1 4}$ \\
\hline $150 \mathrm{~g}$ & $8.23 \pm 2.54$ & $14.98 \pm 6.36^{*}$ & $73.41 \pm 24.59^{*}$ & $91.83 \pm 31.47^{*}$ & $90.81 \pm 24.12 *$ & $149.75 \pm 13.01 *$ & $169.62 \pm 38.98^{*}$ & $202.47 \pm 14.50^{*}$ \\
$300 \mathrm{~g}$ & $7.51 \pm 3.22$ & $14.19 \pm 5.94^{*}$ & $69.96 \pm 20.37^{*}$ & $88.31 \pm 24.38^{*}$ & $107.51 \pm 61.60^{*}$ & $173.46 \pm 58.84^{*}$ & $142.54 \pm 13.52^{*}$ & $138.16 \pm 38.78^{*}$ \\
$600 \mathrm{~g}$ & $7.32 \pm 2.90$ & $16.21 \pm 3.96^{*}$ & $66.85 \pm 30.83^{*}$ & $64.86 \pm 25.43^{*}$ & $87.81 \pm 60.81 *$ & $130.58 \pm 39.66 *$ & $141.85 \pm 34.08^{*}$ & $152.36 \pm 38.57^{*}$ \\
\hline
\end{tabular}

$6225 \mathrm{mg} / \mathrm{kg}$ of crude oil

\begin{tabular}{lllllllll}
\hline BSG & $\mathbf{0}$ & $\mathbf{2}$ & $\mathbf{4}$ & Weeks 6 & $\mathbf{8}$ & $\mathbf{1 0}$ & $\mathbf{1 2}$ & $\mathbf{1 4}$ \\
\hline $150 \mathrm{~g}$ & $10.97 \pm 4.07^{*}$ & $14.93 \pm 4.64^{*}$ & $77.57 \pm 14.90^{*}$ & $90.76 \pm 24.94^{*}$ & $143.41 \pm 18.29^{*}$ & $152.39 \pm 27.30^{*}$ & $160.96 \pm 38.92^{*}$ & $174.47 \pm 53.52^{*}$ \\
$300 \mathrm{~g}$ & $8.89 \pm 3.45$ & $12.20 \pm 5.39^{*}$ & $56.12 \pm 10.96^{*}$ & $80.22 \pm 12.78^{*}$ & $135.21 \pm 28.28^{*}$ & $176.13 \pm 55.19^{*}$ & $169.19 \pm 17.27^{*}$ & $167.30 \pm 22.71^{*}$ \\
$600 \mathrm{~g}$ & $12.22 \pm 3.95^{*}$ & $11.73 \pm 8.81^{*}$ & $71.99 \pm 4.17^{*}$ & $70.70 \pm 22.74^{*}$ & $123.56 \pm 41.88^{*}$ & $125.69 \pm 44.96^{*}$ & $167.90 \pm 17.00^{*}$ & $173.25 \pm 54.10^{*}$ \\
\hline
\end{tabular}

Uncontaminated and un-amended Soil (Control-2).

\begin{tabular}{lllllllll}
\hline & $\mathbf{0}$ & $\mathbf{2}$ & $\mathbf{4}$ & $\mathbf{6}$ & $\mathbf{8}$ & $\mathbf{1 0}$ & $\mathbf{1 2}$ & $\mathbf{1 4}$ \\
\hline Leaf Area & $7.25 \pm 2.22$ & $9.60 \pm 4.81$ & $22.87 \pm 15.21$ & $30.30 \pm 17.19$ & $52.55 \pm 27.94$ & $67.99 \pm 27.32$ & $71.22 \pm 4.72$ & $78.51 \pm 21.25$ \\
\hline
\end{tabular}

Leaf area (LA) was determined by multiplying leaf length by leaf width with the correction coefficient (r) which is 0.72 as proposed by Adesua (2014) [6] Leaf Area was calculated thus: LA = L X W X r

Table 14. Number of flowers of pepper seedlings grown on soil contaminated and treated with different levels of crude oil and BSG amendment respectively. $2075 \mathrm{mg} / \mathrm{kg}$ of crude oil

\begin{tabular}{lllllllll}
\hline BSG & $\mathbf{0}$ & $\mathbf{2}$ & $\mathbf{4}$ & Weeks 6 & $\mathbf{8}$ & $\mathbf{1 0}$ & $\mathbf{1 2}$ & $\mathbf{1 4}$ \\
\hline $150 \mathrm{~g}$ & nil & nil & Nil & Nil & Nil & Nil & nil & Nil \\
$300 \mathrm{~g}$ & nil & nil & Nil & Nil & Nil & Nil & nil & Nil \\
$600 \mathrm{~g}$ & nil & nil & Nil & nil & Nil & 3 Real F. \& 31 F. Buds $\pm 8.44^{*}$ & Nil & Nil \\
\hline
\end{tabular}

$4150 \mathrm{mg} / \mathrm{kg}$ of crude oil

\begin{tabular}{lllllllll}
\hline BSG & $\mathbf{0}$ & $\mathbf{2}$ & $\mathbf{4}$ & Weeks $\mathbf{6}$ & $\mathbf{8}$ & $\mathbf{1 0}$ & $\mathbf{1 2}$ & 14 \\
\hline $150 \mathrm{~g}$ & nil & nil & Nil & nil & Nil & Nil & 20 Real F. $\pm 8.38^{*}$ & Nil \\
$300 \mathrm{~g}$ & nil & nil & Nil & nil & Nil & Nil & Nil & Nil \\
$600 \mathrm{~g}$ & nil & nil & Nil & nil & Nil & Nil & Nil & Nil \\
\hline
\end{tabular}

$6225 \mathrm{mg} / \mathrm{kg}$ of crude oil

\begin{tabular}{|c|c|c|c|c|c|c|c|c|}
\hline BSG & 0 & 2 & 4 & Weeks 6 & 8 & 10 & 12 & 14 \\
\hline $150 \mathrm{~g}$ & nil & nil & Nil & nil & Nil & Nil & nil & F. Buds $6.00 \pm 2.06^{*}$ \\
\hline $300 \mathrm{~g}$ & nil & nil & Nil & nil & F. Buds $5.00 \pm 2.17 *$ & Nil & Real F. $40.00 \pm 17.32 *$ & Nil \\
\hline $600 \mathrm{~g}$ & nil & nil & Nil & nil & F. Buds $3.00 \pm 1.30 *$ & F. Buds $8.00 \pm 3.46^{*}$ & nil & Nil \\
\hline
\end{tabular}

Comment: A fungus attacked the pepper seedlings on the first week of January, 2016 (14 ${ }^{\text {th }}$ Week of study). The fungus withered and detached all the flowers, leaving only one that gave birth to one surviving fruit [the seedling planted on wooden microcosm contaminated with $4150 \mathrm{mg} / \mathrm{kg}$ Crude oil and amended with $150 \mathrm{~g} \mathrm{BSG}]$

Key: nil = No flower(s); while F. Buds = flower buds and Real F. = real flower.

Uncontaminated and un-amended Soil (Control-2).

\begin{tabular}{lllllllll}
\hline & $\mathbf{0}$ & $\mathbf{2}$ & $\mathbf{4}$ & $\mathbf{6}$ & $\mathbf{8}$ & $\mathbf{1 0}$ & $\mathbf{1 2}$ & $\mathbf{1 4}$ \\
\hline Number of Flowers & Nil & nil & nil & nil & Nil & Nil & nil & Nil \\
\hline
\end{tabular}

Note: There were no sign of flowers at all on pepper seedlings planted on plastic microcosm throughout the period of the study (Control-2), even before the fungal attack.

Table 15. Number of fruits of pepper seedlings grown on soil contaminated and treated with different levels of crude oil and BSG amendment respectively. $2075 \mathrm{mg} / \mathrm{kg}$ of crude oil

\begin{tabular}{lllllllll}
\hline BSG & $\mathbf{0}$ & $\mathbf{2}$ & $\mathbf{4}$ & Weeks $\mathbf{6}$ & $\mathbf{8}$ & $\mathbf{1 0}$ & $\mathbf{1 2}$ & $\mathbf{1 4}$ \\
\hline $150 \mathrm{~g}$ & nil & nil & nil & nil & nil & nil & Nil & Nil \\
$300 \mathrm{~g}$ & nil & nil & nil & nil & nil & nil & Nil & Nil \\
$600 \mathrm{~g}$ & nil & nil & nil & nil & nil & nil & Nil & Nil \\
\hline
\end{tabular}


$4150 \mathrm{mg} / \mathrm{kg}$ of crude oil

\begin{tabular}{lllllllll}
\hline BSG & $\mathbf{0}$ & $\mathbf{2}$ & $\mathbf{4}$ & Weeks $\mathbf{6}$ & $\mathbf{8}$ & $\mathbf{1 0}$ & $\mathbf{1 2}$ & $\mathbf{1 4}$ \\
\hline $150 \mathrm{~g}$ & nil & nil & nil & nil & nil & nil & nil & 1 \\
$300 \mathrm{~g}$ & nil & nil & nil & nil & nil & nil & nil & Nil \\
$600 \mathrm{~g}$ & nil & nil & nil & nil & nil & nil & nil & Nil \\
\hline
\end{tabular}

Note: Only one of the pepper seedlings planted on microcosm contaminated with $4150 \mathrm{mg} / \mathrm{kg}$ Crude oil and amended with $150 \mathrm{~g}$ BSG produced one fruit out of all seedlings that bore flowers. This was due to the fungal attack in that all other flowers withered and fell-off.

$6225 \mathrm{mg} / \mathrm{kg}$ of crude oil

\begin{tabular}{lllllllll}
\hline BSG & $\mathbf{0}$ & $\mathbf{2}$ & $\mathbf{4}$ & Weeks $\mathbf{6}$ & $\mathbf{8}$ & $\mathbf{1 0}$ & $\mathbf{1 2}$ & $\mathbf{1 4}$ \\
\hline $150 \mathrm{~g}$ & nil & Nil & nil & nil & nil & Nil & Nil & Nil \\
$300 \mathrm{~g}$ & nil & Nil & nil & nil & nil & Nil & Nil & Nil \\
$600 \mathrm{~g}$ & nil & Nil & nil & nil & nil & Nil & Nil & Nil \\
\hline
\end{tabular}

Key: nil $=$ No fruit

Uncontaminated and un-amended Soil (Control-2).

\begin{tabular}{lllllllll}
\hline & $\mathbf{0}$ & $\mathbf{2}$ & $\mathbf{4}$ & $\mathbf{6}$ & $\mathbf{8}$ & $\mathbf{1 0}$ & $\mathbf{1 2}$ & $\mathbf{1 4}$ \\
\hline Number of Fruits & Nil & Nil & nil & nil & Nil & Nil & Nil & Nil \\
\hline
\end{tabular}

Note: Asterisks $(*)$ shows significance difference $(\mathrm{P}=0.05)$.

\section{Discussion}

\subsection{Influence of Crude oil and BSG Amendment on Soil Physicochemistry}

The results of the soil physical and chemical characteristics (Table 1) have shown that the test is predominantly sandy. The particle size arrangement of soil determines the texture of the soil, while soil texture determines the water absorption capacity, water storage, ease of tilling as well as soil aeration and fertility (Dias et al., 2012) [18]. The $\mathrm{pH}$ range of 5.67 revealed a strongly acid soil and acid soils are known to exhibit intensive leaching, low exchangeable basic cations content and slow microbial activity (Adesua, 2014) [6]. The total organic carbon and phosphorus content of the soil used for the study are low with the percentage availability of $0.05 \%$, and $0.026 \%$ respectively. There were also appreciable levels of other trace elements. With mean of $0.05 \%$, the TOC level of test soil was less than $12 \%$ reported for soils derived from mineral sources (Dias et al., 2012) [18] and is in consistent with findings of previous reports on the study area (Adesua, 2014) [6]. However, contamination of test soil increased the TOC of the soil to range of $0.14-0.21 \%$, the TON was reduced from 0.39 to $0.21-0.28$ depending on the level of contamination.

Cations are positively charged ions present in the soils and can undergo displacement reactions that are important in soil fertility, in correcting soil acidity/alkalinity, in changes altering soil physical properties, and as a mechanism in purifying or altering percolating waters. Exchangeable cations in soil are easily dissolved into solutions making them readily available for uptake by roots of plants. Calcium $(\mathrm{Ca})$, magnesium $(\mathrm{Mg})$, sodium $(\mathrm{Na})$ and Potassium $(\mathrm{K})$ are the most abundant cations on the exchange sites in soils. They also help in cleansing the soil by providing adsorption/exchange sites for potential soil and water pollutants (trace metals such as lead and cadmium ions). The addition of BSG to soil had little or no influence on the 2.835 $\mathrm{mg} / \mathrm{kg}, 1.683 \mathrm{mg} / \mathrm{kg}, 10.471 \mathrm{mg} / \mathrm{kg}$ and $0.956 \mathrm{mg} / \mathrm{kg}$ of $\mathrm{Ca}$, $\mathrm{K}, \mathrm{Na}$ and $\mathrm{Mg}$ respectively, detected in the test soil.

The low level of carbon, nitrogen and phosphorus $(\mathrm{C}, \mathrm{N}$ and $\mathrm{P}$ ) in the garden soil samples might have been caused by leaching/ erosion. Researchers noted that the addition of these limiting nutrients is a key factor in achieving effective biodegradation of hydrocarbons. The amendement increased the $\mathrm{pH}$ range of the experimental samples from 5.58 to 6.31 . This range is within the favorable range for biodegradation of crude oil in polluted soil. Similar observations have been reported by Adesua (2014) [6] and Akoachere et al. (2008) [9]. The pH range of the organic amendment (6.64) is also in line with the recommended optimal environmental conditions necessary for microbial degradation of crude oil contaminated soil (Table 1). The BSG was also characterized with high level of the total organic carbon (10.7\%), phosphorus $(0.75 \%)$ and nitrogen $(10.1 \mathrm{mg} / \mathrm{kg})$. Similar results have been reported by Kim et al., (2005) [33] and Okoh, (2006) [41]. Tang et al., (2009) [52] and Senthilkumar, et al (2010) [49] have reported that BSG contained appreciable percentage of crude protein (17.8\%), cellulose $(24.6 \%)$ and lignocelluloses $(30.2 \%)$. It shows that Brewers' spent grains are of high nutritive value. Essien and Udotong (2008) [24] also reported detection of amino acids in BSG. Cellulose content of $25 \%$ detected in BSG as one of the highest cellulose value recorded for organic amendments (Yao et al., 2012) [56]. There is also an appreciable amount of a nutritive salt of potassium as $2.9 \mathrm{mg}$ / Addition of organic amendment (BSG) also improves soil structure and waterholding capacity by binding sand particles and increasing silt contents (Adesua, 2014) [6].

Negative influences of crude oil contaminated soils result to insufficient plant nutrients, reduction in microbial 
population and the deterioration of soil structure Adesua (2014) [6]. The need to effectively and efficiently remedy these soils has led to the use of a wide range of physical, chemical and biological techniques. The result of study shows that BSG is rich in nutrients and can be effectively used for the restoration of nutrients and conditions necessary for effective plant growth.

\subsection{Influence of BSG Amendment on Microbial Activities of Contaminated Soil}

Hydrocarbons are usually adsorbed by organic matter in soils. Desorption of the contaminants becomes very slow and may slow the rate of biodegradation. Addition of organic amendment (BSG as in this study) brings to an end this difficulty and enhances degradation process by increasing microbial population of the soil (Oruru, 2014) [44]. It is known that hydrocarbon biodegradation in soil can be limited by many factors, such as microorganism type, nutrients, $\mathrm{pH}$, temperature, moisture, oxygen, soil properties, and contaminant concentration (Bradi et al., 2000 [15]; Semple et al., 2001 [48]; Sabate et al., 2004 [47]; Ghazali et al., 2004 [27]; Walter et al., 2005 [55]; Atlas and Bartha, 2006) [11]. The degradation of organic materials usually results in increase in soil moisture and temperature and enhances further biological activities (Hollday and Deuel, 1994 [28]; Hou and Al-Tabbas, 2014) [29]. Therefore, increase in nutrient properties of the amended "oiled" soils are attributed to organic amendment which on decomposition supplied conditions necessary for microbial activity for the release of nutrients (Hollday and Deuel, 1994 [28]; and Adesua, 2014) [6].

Crude oil in the environment is biodegraded primarily by bacteria and fungi. The reported efficiency of biodegradation ranged from $6 \%$ to $82 \%$ for soil fungi, 0.13 to $50 \%$ for soil bacteria and 0.003 to $100 \%$ for marine bacteria. Though algae and protozoa are important members of terrestrial and aquatic ecosystems, reports are scanty regarding their role in hydrocarbon biodegradation. However several reports reveal that mixed populations of crude oil utilizing microorganisms with overall broad enzymatic capacities are require to degrade complex mixtures of hydrocarbon such as crude oil in soil, fresh water and marine environment (Das and Mukherjee, 2007) [17], Senthilkumar et al., 2010) [49]. Figures 1 to 5 have shown that depending on the level of contamination and amount of amendment added, BSG improves the soil heterotrophic bacteria properties and indirectly, the hydrocarbonoclastic bacteria activities of soil. The later is attained by increased in the nitrogen and phosphosprus levels of contaminated soil which enhances the activities of the oil degraders. In addition to a readily degradable carbon source, microorganisms require nutrients such as nitrogen, phosphorus, and potassium (NPK) for cellular metabolism and successful growth (Sihag and Pathak, 2014) [50]. In a contaminated site where organic carbon levels are always high, available nutrients can rapidly be depleted during metabolism (Okerentugba et al., 2003) [40]. Therefore, it is very important to supplement contaminated soil with nutrients generally nitrogen and phosphorus to complement carbon utilization by the microorganisms. The amount of nitrogen required to establish bioremediation is a site specific value, and can be determined through preliminary investigation and conceptual site modeling. Previous reports show that a contaminated soil adjusted to $\mathrm{C}$ : $\mathrm{N}$ : P ratio of 120: 10: 1; 100: 15: 3; 5: 1: 0.5; 25:1:1 will be able to drive the biodegradation of petroleum hydrocarbon (Kaczorek et al., 2013 [32]; Silag and Pathak, 2014) [50]. The ratio of the C:N:P as demonstrated by Kaczorek, et al is in line with the quantity of $\mathrm{C}: \mathrm{N}: \mathrm{P}$ as analyzed in this research in table 1 . The results from table 1 above also provided the required nutrients. The type and quantity of nutrients added into a polluted soil affects the bioremediation of such environment. In view of this, most researchers have used organic fertilizer to supply limiting nutrients to microorganisms degrading crude oil in the environment but this research used BSG in place of organic fertilizer to supply limiting nutrients to hydrocarbonoclastic microbes.

Crude oil degradation can occur under aerobic and anaerobic conditions (Okoh, 2006 [41], Adesua, 2014) [6]. In general, aerobic metabolism of hydrocarbons initially requires oxygenase enzymes which incorporate molecular oxygen into the reduced substrate. Most microorganisms attack alkanes terminally whereas some perform sub-terminal oxidation. The alcohol product is oxidized finally into an aldehyde and finally to a fatty acid. The latter is degraded further by beta-oxidation (Abioye et al., 2012) [1]. Generally, the mechanisms involved in the degradation of petroleum hydrocarbons include mediation by specific enzyme system (e.g oxygenase, hydroxylases), attachment of microbial cells to the substrates and production of extracellular emulsified agents called biosurfactants e.g. rhamnolipids, gylcolipid, surfaction) by hydrocarbon degrading microorganisms (Walter et al., 2005 [55], Ghazali et al., 2004 [27], Das and Murkherjee, 2007 [17] and Kaczorek et. al; 2013) [32]. The results of this study presented on Table 5 and Figures 5 and 6 have shown an enhanced degradation of oil in contaminated soil however the rate of degradation varied with the level of contamination and amount of BSG amendment added to soil. It implies that BSG can serve as nutrient rich bio-stimulants (bio-fertilizer) to improve the poor nutritional status of the soil and enhance bioactivities.

This study has also revealed remarkable increase in activities of oil degrading bacteria on the 8th week of the remediation course. The growth and reproduction / proliferation of hydrocarbon-degrading-microbes affected the biodegradation process in contaminated soil. The counts of crude oil utilizing bacteria in the polluted soil samples amended with BSG were appreciably higher compared with those in non-amended (control-2) soil. The reason for higher counts of bacteria in amended soil might be as a result of presence of appreciable quantities of nitrogen and phosphorus in the BSG. These elements are necessary nutrients for bacterial bio-degradation activities. The BSG may have also served as bulking agent which helped to loosen the compactness of the soil making sufficient aeration 
available for the indigenous bacteria present in the soil, thereby enhancing their metabolic activities in the contaminated soil (Joo et al., 2007 [31]; Abioye et al., 2012) [1]. Their activity reduces the impact of crude oil and tended to resuscitate the activities of Nitrobacter and Nitrosomonas in contaminated soil (Figures 4). This justifies the fact that higher concentration of the pollutants may have retarded the growth of nitrogen fixers in soil. These findings have shown that BSG has the capability to neutralize the toxic effects of crude oil on microbial population by rapid improvement of the soil physicochemical properties. This has earlier been asserted by Akoachere et al., (2008) [9] and Mbah et al (2009) [34]. The presence of limiting nutrients in the amendment (BSG) suggested that BSG played the role of biostimulation in the biodegradation process.

The level of biodegradation of crude oil after 14 days of amendment (biodegradation) with BSG is shown in Table 5. There was a rapid reduction in the total petroleum hydrocarbon within the first 14 days of the study in all the soil amended with BSG compared with that of un-amended soil. Adesua, (2014) [6] have reported a significant increment in the rate of bioremediation of oil-polluted soil with increase in bacteria population. At the end of the 14 days, $150 \mathrm{~g} \mathrm{BSG}$ and $20 \mathrm{~kg}$ of soil contaminated with $2075 \mathrm{mg} / \mathrm{kg}$ crude oil had highest degradation rate $(62.09 \%)$ after 14 days as against $4.14 \%$ recorded for soil with $6225 \mathrm{mg} / \mathrm{kg}$ of crude oil after amendment with $150 \mathrm{~g}$ of BSG.

\subsection{Influence of BSG Amendment on Pepper Grown in Oil Contaminated Soil}

Oil spillage has been known to exhibit various deleterious effects on both plants and microorganisms especially in terrestrial ecosystem. Crude oil spillage on soil generally retard plant growth (Adesua, 2014 [6]; Ayotamuno et al., 2006 [13]; Banwo, 2013 [14]; Ekpo and Nwankpa, 2005) [20], reduces aeration by blocking air spaces between soil particles hence create condition of anaerobiosis (Adesua, 2014) [6] and causes root stress in plant which also reduces leaf growth (Abioye et al., 2012 [1] and Yao et al, 2012) [56]; chloriosis (yellowing of leaf) also occurs. Other researchers discovered that Spent engine oil like other petroleum products adversely affects the growth and performance of plants (Okon and Mbong, 2013) [42]. The effect of the spent engine oil on the plant height was also reported on the effect of spent oil on Amaranthus hybridus (Odjegba and Sadiq, 2002) [39]. (Njoku, Akinola, and Oboh, 2008) [37] also found similar findings on the effect of crude oil on the growth accessions of Glycine max and Lycopersicon esculentum. (Adedokun and Ataga, 2007) [4]. (Adedokun and Ataga, 2007) [4] also showed that treatment of soils with crude oil, automotive gasoline oil and spent engine oil significantly affected the time of germination, percentage germination, plant height, leaf production and biomass of $V$. unguiculata delaying germination and growth rate. (Okon, Esenowo and Umoh, 2012) [43] also reported that crude oil at high concentrations show adverse effect on tubers production of Manihot esculenta but organic supplements were found to reduce the toxic effects of crude oil. Umoh and Esenowo (1996) [54] also reported the toxic effects of used engine oil soil pollution on growth and yield of Arachis hypogea and Zea mays. (Sun, Lo, Robert, Ray and Tang, 2004) [51] made similar observation when they studied the effect of diesel fuel on the growth of Nerlum oleander, beach naupaka, false sandalwood, common ironwood, kou, milo and kiawe. (Umohand Esenowo, 1996) [54], availability of nitrogen in the soil directly affects the relative growth rate of plants. It was also discovered that petroleum-products are known to reduce nitrogen availability (Agbogidi, Eruotor, Akparobi and Nnaji, 2007) [8]. Dimitrow and Markow (2000) [19] showed that the presence of oil in the soil significantly decreased the available forms of phosphorus and potassium to plants.

Various substances and materials when applied to plants or growing substrates demonstrate capacity to modify the physiology of plants, promoting their growth and enhancing their growth response. Their action is different from that of nutrients and plant pesticides thus the term bio-stimulant has been coined to describe the function. Bio-stimulant can be defined as organic substances and material, that when applied in small quantities enhance plants growth and development that such response cannot be attributed to application of the traditional nutrients (Gallant, 2004) [26]. Biostimulants have been shown to influence several metabolic processes such as respiration, photosynthesis, nucleic acid synthesis and ion uptake. They are not fertilizers meant to correct a severe nutrients deficiency but they are mixtures of one or more things such as microorganisms, trace elements, enzymes/plants hormones and seaweeds extracts. They contain substances and or microorganisms whose function when applied to plants or the rhizosphere is to stimulate natural processes to enhance nutrient uptake, nutrient efficiency, and tolerance to abiotic and biotic stress. Biostimulants have no direct action against pest therefore do not fall with the regulatory frame work of pesticides.

In this study the effects of the organic amendment (BSG) on the growth of Capsicum annum L cultured on crude oil contaminated soil was apparent. Crop grown in amended soil performed better. The results presented on Table 6 have shown that amendment (BSG) actually influenced the growth of pepper in a crude oil contaminated soil. The effects varied with the level of contamination and amount BSG used as amendment. Pepper grown in soils laden with $2075 \mathrm{mg} / \mathrm{kg}$ and $6225 \mathrm{mg} / \mathrm{kg}$ of crude oil contaminated soils but amended with $300 \mathrm{~g}$ of BSG exhibited the highest height of 90.40 and $69.93 \mathrm{~cm}$ respectively. These are indicative of a significant increase $(\mathrm{P}=0.05)$ in height of pepper seedlings compared with height values recorded for both the positive and negative controls. The uncontaminated and un-amended soil (Control 1) recorded the least height of $27.40 \mathrm{~cm}$. Retardation in growth of pepper plants (stunted growth, less leaf formation, failure to flower and produce branches) by crops grown in contaminated soils not treated with BSG might be ascribed to low levels of N, P and high Ca levels in impacted soil. Nitrogen and phosphorus are growth promoters as they are constituents of protein. In addition, high carbon content in the soil relative to $\mathrm{N}$ results in competition for $\mathrm{N}$ between 
microbial population and plants with $\mathrm{N}$ being less available to plants (Oruru, 2014) [44]. Mineralization of decomposable carbon, nitrogen compounds, organic compounds, and organic colloids in BSG provided energy source and nutrients for plants than in garden soil with nil BSG (Adesua, 2014 [6] and Oruru, 2014) [44].

Nutrients contained in the organic sources are readily available to crop uptake after they are mineralized and released in the soil (Odedina et al. 2003) [38]. It is possible that the manure (BSG) stimulated Pepper growth as a result of increased nutrient availability. The results show that in the presence of reasonable quantity of BSG and crude oil promotes crop production in an optimal environmental condition. Also, the result of the physicochemical properties of the BSG used showed high influence of the organic amendment (BSG) on the microbial activity on the crude oil contaminated soil. The BSG used is a good growth medium for heterotrophic microorganisms and enzyme production in that the cellulose, lignocelluloses, mineral matter and protein content of the BSG make it particularly susceptible to microbial growth and degradation. The BSG also may serve as ready source of nutrients required by indigenous microflora to initiate the hydrocarbon degradation processes and general mineralization of organic matter within the shortest time, in an attempt to utilize it as sole carbon source (Abioye et al., 2012) [1].

The effects of crude oil on the growth and performance of plants have been reported in many researches. Okon, Esenowo and Umoh, (2012) [43] reported that crude oil at high concentrations show adverse effect on tubers production of Manihot esculenta but organic supplements were found to reduce the toxic effects of crude oil. These effects have been observed to occur due to the interference of the plant uptake of nutrients by crude oil and the unfavourable soil conditions due to pollution with crude oil (Adesua, 2014 [6]; Abioye et al, 2012 [1]; Agamuthu and Dadrasuia, 2013) [7]. It has been reported that plants and soil microbes compete for the little nutrient available in soils that are not rich like the soil polluted with crude oil thereby suppressing the growth of plants in such soils. However, it is generally known that when soils not suitable for plant growth are augmented with manure, growth and performance of plants in such soil are enhanced. Merkl et al (2005) [35] reported that addition of inorganic fertilizer in a crude oil polluted soil enhances the growth and performance of Brachiaria brizantha in crude oil polluted soil. Although, the performance of plants as reported by Merkl and co--workers can be enhanced in crude oil polluted soil with fertilizer, it also increases the cost of crop production in crude oil polluted soil. This study has revealed the potential of BSG as a cheap and alternative source of organic amendment for enhanced plant growth in crude oil contaminated soils.

\section{Conclusion and Recommendations}

The study has shown that the nutrients (nitrogen, phosphorus and potassium) in BSG are not only essential to plant growth and development but also enhances microbial activities which help to reduce the shielding influence of crude oil or "unmask" the nutrients, making them readily available for uptake by crops. Further research is recommended on the potential of BSG as a conditioner and biofertilizer in an open field (like a hectare of land) trial to ascertain its efficacy in the clean up hydrocarbon contaminated soil. Villagers especially subsistence and commercial farmers could also use it to replenish organic nutrients in a barren land and also to support their crop production in place of inorganic fertilizers. This is because BSG cannot cause ocean acidification as an after-effect of leaching or run-off in farm lands.

\section{References}

[1] Abioye, O. P., Agamuthu, P., and Abdul Aziz, A. R (2012) 'Biodegradation of used motor oil in soil using organic waste amendments' journal of Biotechnology Research International Vol. 2012 pp. 1-8.

[2] Abu, G. O and Dike O. P (2008) 'A study of natural attenuation processes involved in a microcosm model of crude oil-impacted wetland sediment in Niger Delta' Bioresource Technology. Vol 99 pp. 4761-4767.

[3] Adekunle, M. I., (2011) 'Bioremediation of soils contaminated with Nigerian petroleum products using composted municipal wastes' bioremediation journal Vol 15 (4) pp. 230-241.

[4] Adedokun, O. M. and Ataga, A. E. (2007). Effects of amendments and bioaugumentation of soil polluted with crude oil, automotive gasoline oil, and spent engine oil on the growth of cowpea (Vigna ungiculata Walp L.). Scientific Research and Essay, 2 (5): 147-149.

[5] Adesodun, J. K., \& Mbagwu J. S. (2008) 'Biodegradation of waste lubricating petroleum oil in a tropical alfisol as mediated by animal droppings' Bioresource Technology Vol. 85 (13) pp. 5659-5665.

[6] Adesua Teresa Ojeamiren (2014) A Comparative Analysis of Diesel Contaminated Soils Bioremediation with Brewery Spent Grain and Paper Waste. Unpublished MSc Thesis, Department of Environment, Health and Safety, Faculty of Applied Sciences, University of Sunderland, United Kingdom.

[7] Agamuthu, P., and Dadrasnia, A. (2013) 'Potential of biowastes to remediate diesel fuel contaminated soil' Journal of Global nest Vol 15 (4) pp. 474-484.

[8] Agbogidi, O. M., Eruotor, P. G., Akparobi, S. O. and Nnaji, G. U. (2007). Evaluation of crude oil contaminated soil on the mineral nutrient elements of maize (Zea mays L.). J. Agron., 6(1): 188-193.

[9] Akoachere, J. T. K., Akenji, T. N., Yongabi, F. N., Nkwelang, G. and Ndip, R. N (2008). Lubricating oil degrading bacteria in soils from filling stations and auto-mechanic workshops in Buea, Cameroon: occurrence and characteristics of isolates. African. J. Biotechnol. 7, 1700-1706.

[10] AOAC (2005) Association of Official Analytical Chemist, Official Methods of Analysis $18^{\text {th }}$ edition Washington D. C. USA. 
[11] Atlas, R. M., and Bartha, R., (2006). "Fate and effects of polluting petroleum in the marine environment". Residue Rev. 49 (1): 49-83.

[12] Aweke Kebede and Taddese Wondimu (2004) Distribution of Trace Elements in Muscle and Organs of Tilapia, Oreochromis Niloticus, from lakes Awassa and Ziway, Ethiopia, Bull. Chem. Soc. Ethiop. 2004, 18 (2), 119-130.

[13] Ayotamuno. M. J., Kogbara R. B., Ogaji S. O. T., Probert, S. D., (2006) 'Bioremediation of a crude-oil polluted agricultural-soil at Portharcourt, Nigeria.' Journal of Applied Energy. Vol 83 (11) pp 1249-1257.

[14] Banwo, O. O., (2013) 'Critical evaluation of the use of brewery spent grain in bioremediation'. Msc Dissertation, University of Sunderland.

[15] Bradi, L., Mattei, A., Steffan, S., and Marzona, M., (2000). "Hydrocarbon degradation by a soil microbial population with $\beta$-cyclodeztrin as surfactant to enhance bioavailability". Enzyme and Microbial Technology: 27 (3); 709-713.

[16] Cheesbrough, M., 2006. District Laboratory Practice in Tropical Countries. 2nd Edn., Cambridge University Press, Cambridge, UK., ISBN-13: 9781139449298.

[17] Das, K., and Murkherjee, A. K., (2007). "Crude petroleumoil biodegradation efficiency of Bacillus subtilis and Pseudomonas aeruginosa isolated from a petroleum-oil contaminated soil from North-East India". Bioresource Technology., 98 (2): 1339-1345.

[18] Dias, R., Ruberto, L., Hernandez, E., Vazquez, S., Balbo A., Panno, M., Cormack, W., (2012) 'Bioremediation of an aged diesel oil-contaminated antartic soil evaluation of the 'On site' biostimulation strategy using different nutrient sources' international biodeterioration and biodegradation Vol. $75 \mathrm{pp}$. 96-103.

[19] Dimitrow, D. N. and Markow, E. (2000). Behaviour of available forms of NPK in soils polluted by oil products. Poczwoznanie, Agrochimija Ekologia, 35 (3): 3-8.

[20] Ekpo M. A, and Nwaankpa, I. L. (2005). Effect of crude oil on microorganisms and growth of ginger (Zingiber officinale) in the tropics. J. Sustainable Trop. Agric. Res. 16: 67-71.

[21] Ekudanyo, E. O., and Obuekwe, O. O. (2004). "Effect of oil spill on soil physico-chemical properties of a spill site in a Typical Udipsamment of Niger Delta basin of Nigeria". Environmental Monitoring and Assessment, Springer Netherlands, vol. 60, no. 2, pp. 235-249.

[22] Emufurieta, W. O., Kayode, A. A. \& Coker, S. A. (1992). Mineralogy, geochemistry and economic evaluation of kaolin deposit near Ubulu - Uku, Awo- Omana and Buan in Southern Nigeria. Journal of Mineralogy and Geology, 28, 210 - 281.

[23] Encyclopædia Britannica. (2012). Encyclopcedia Britannica Ultimate Reference Suite. Chicago: Encyclopædia Britannica.

[24] Essien, J. P., Udotong, I. R. (2008). Amino Acid Profile of Biodegraded Brewers Spent Grains (BSG). J. Appl. Sci. Environ. Manage. 12 (1): 109-111.

[25] Essien, J. P., Ebong, G. A., Asuquo, J. E., and Olajire, A. A (2012). Hydrocarbons contamination and microbial degradation in mangrove sediments of the Niger Delta region (Nigeria).

[26] Gallant Adrien TURF and Recreation (2004). Biostimulants: what they are and how they work.

[27] Ghazali, F. M, Rahman, RNZA, Salleh, A. B and Basri, M (2004). Biodegradation of hydrocarbons in soil by microbial consortium. Intl. Biodeter. Biodegrad. 54: 61-67.

[28] Hollday, C. H. and Deuel, L. E. (1994). Hydrocarbon and produced water contaminated soil and waste remediation, soil remediation for petroleum extraction industry, soil remediation seminar text. American petroleum institute publication, Washington D. C.

[29] Hou, D., and Al-Tabbaa A. A (2014) 'Sustainability: A new imperative in contaminated land remediation' Environmental Science and Policy Vol. 39 pp. 25-34.

[30] Institute of Petroleum. (IP) (2001). Standard Methods. The Institute of Petroleum, London, UK.

[31] Joo, H. S., Shoda, M. and Phae, C. G. (2007). Degradation of diesel oil in soil using a food waste composting process. Biodegradation 18 (5): 597-605.

[32] Kaczorek, I., Salek, K., Guzik, U., Teofil, J., and Cybulski, Z. (2013) 'Biodegradation of alkyl derivatives of aromatic hydrocarbon and cell surface properties of a strain of pseudomonas stutzeri' chemosphere Vol. 90(2) pp. 471-478.

[33] Kim, S. J., Choi, D. H., Sim, D. S. and Oh, Y. S. (2005) "Evaluation of bioremediation effectiveness on crude oilcontaminated sand," Chemosphere 59(6): 845-852.

[34] Mbah, C. N., Nwite, J. N. and Nweke, I. A. (2009). Ameriolation of spent oil contaminated ultisol with organic wastes and its effect on soil properties and maize (Zea mays $L$ ) yield. World. J. Agric. Sci. 5(2), 163-168.

[35] Merckl, N., Schutze-Kraft, R and Arias, M. (2005). Influence of fertilizer level on phytoremediation of crude oilcontaminated soils with the tropical grass Brachiaria brizantha (Hochst. ex A. Rich.) Stapf. In: Phytoremediation of petroleum-contaminated soil. Merkl, N. (Ed), Margraf Publisher, Weikershim; pp 71-83.

[36] Miyashi, K., Sato, J. and Takahashi, N. (1996). Difference in the Effects of Dehusking during Formation of Seeds on Germination of Indica and Japaonia Rice (Oryza sativa L.). Annals of Botany, 71(8): 569-604.

[37] Njoku, K. L., Akinola, M. O. and Oboh, B. O. (2008). Germination, survival and growth of accession of Glycine max L. (Merril) (Soybean) and Lycopersicon esculentum L. (Tomato) in crude oil polluted soil. Res. J. Environ. Toxicol., 2(2): 77-84.

[38] Odedina, S. A., S. O. Odedina, S. Ayeni, A. A. Arowojolu, S. D. Areyeye and S. O. Ojeniyi, (2003). Effects of types of wood ash on soil fertility nutrient availability and yield of tomato and pepper. Niger. J. Soil Sci., 13: 61-67.

[39] Odjegba, V. and Sadiq, A. O. (2002). Effects of spent engine oil on the growth parameters, chlorophyll and protein levels of Amaranthus hybridus L. The Environmentalist, 22: 23-28.

[40] Okerentugba, P. O. and Ezeronye, O. U. (2003). Petroleum degrading potentials of single and mixed microbial cultures isolated from rivers and refinery effluents in Nigeria. Afr. $J$. Biotechnol. 2(9): 288-292.

[41] Okoh, I. A. (2006). Biodegradation Alternative in the Clean up of Petroleum Hydrocarbon Pollutants. Biotech. Mol. Biol. Rev. 1 (2): 38-50. 
[42] Okon, J. E and Mbong, E. O. (2013). Effects of Nutrient Amendments of Spent Engine Oil Polluted Soil on Some Growth Parameters of Abelmoschus esculentus (L.) Moench. in South-South Nigeria. Bulletin of Environment, Pharmacology and Life Sciences Bull. Env. Pharmacol. Life Sci., Vol 2 (5) April 2013: 75-78 C2013 Academy for Environment and Life Sciences, India Online ISSN 2277-1808.

[43] Okon, J. E., Esenowo, G. J. and Umoh, N. S. (2012). Effect of Crude Oil Pollution of Soil and Amelioration Treatment on the Growth of Eight Varieties of Manihot esculenta Crantz. International Journal of Chemical, Environmental and Pharmaceutical Research, 3 (2): 163-169.

[44] Oruru, J. A. (2014) 'Is the use of brewery spent grain in bioremediation of diesel contaminated soil sustainable' $\mathrm{PhD}$. Dissertation University of Sunderland, UK.

[45] Raimi, M. O. (2008). The Effect of Vehicular Emission on Human Health, A Case Study of Yenagoa Motor Parks. Unpublished, A Seminar Paper Presented to the Department of Geography and Environmental Management, Niger Delta University, Wilberforce Island, Bayelsa State.

[46] Rainbow, A. and F. N. Wilson. (2002). Composting for Soil Improvement in the United Kingdom. In: Proceedings of the 12th International Soil Conservation Organization Conference. May 26-31, Beijing, China. Pp 63-67.

[47] Sabate, J., M. Vinas and A. M. Solanas, (2004). Laboratory scale bioremediation experiments on hydrocarbon contaminated soils. Intl. Biodeter. Biodegrad., 54: 19-25.

[48] Semple, K. T., Reid, B. J, and Fermor, T. R., (2001). "Impact of composting strategies on the treatment of soils contaminated with organic pollutants". Environmental Pollution. 112 (1): 269-283.

[49] Senthilkumar, S., T. V. Viswanathan, A. D. Mercy, P. Gangadevi, K. Ally and K. Shyama (2010.) Chemical composition of brewery waste Tamilnadu $J$. Veterinary \& Animal Sciences 6 (1) 49-51.

[50] Sihag, S. and Pathak, H. (2014) Factors Affecting the Rate of Biodegradation of Polyaromatic Hydrocarbons. International Journal of Pure Applied Bioscience [online]. 2 (3), pp. 185202.

[51] Sun, W. H., Lo, J. B., Robert, F. M., Ray, C. and Tang, C. S. (2004). Phytoremediation of petroleum hydrocarbons in tropical coastal soil: I. Selection of promising woody plants. ESPR-Environ. Sci. Pollut. Res., 11 (4): 260-266.

[52] Tang, D., Yin, G., He, Y., Hu, S., Li, B., Li, L., Liang, H., and Borthakur, D. (2009). Recovery of protein from brewer's spent grain by ultrafiltration. Biochem. Eng. J. 48: 1-5.

[53] Tian Y, Liu HJ, Zheng TL, Kwon KK, Kim SJ, Yan CL (2008) PAHs contamination and bacterial communities in mangrove surface sediments of the Jiulong River Estuary, China. Mar Pollut Bull 57: 707-715.

[54] Umoh, N. S. and Esenowo, G. J. (1996). Effects of used engine oil soil pollution on growth and yield of Walker, R. L., Burns, I. G. and Moorby, I. (2001). Response of plant growth rate to nitrogen supply: A comparison of relative addition and nitrogen interruption treatments. J. Expt. Bot., 52 (355): 309317.

[55] Walter, M., Boyd-Wilson, K. S. H., McNaughton, D., Northcott, G., (2005). "Laboratory trials on the bioremediation of aged pentachlorophenol residues". J. Int. Biodeter \& Biodegr, 55 (3): 121-130.

[56] Yao, Z., Li, J., Xie, H., Conghai, Y., (2012) 'Review on remediation technologies of soil contaminated by heavy metals' procedia environmental sciences Vol. 16 pp. 722-729. 